$1-1-1943$

\title{
Forest-land utilization in Nicolas and Webster counties West Virginia
}

\author{
E. C. Weitzell
}

Leonard F. Miller

Follow this and additional works at: https://researchrepository.wvu.edu/ wv_agricultural_and_forestry_experiment_station_bulletins

\section{Digital Commons Citation}

Weitzell, E. C. and Miller, Leonard F., "Forest-land utilization in Nicolas and Webster counties West Virginia" (1943). West Virginia Agricultural and Forestry Experiment Station Bulletins. 309.

https://researchrepository.wvu.edu/wv_agricultural_and_forestry_experiment_station_bulletins/310 @ WVU. It has been accepted for inclusion in West Virginia Agricultural and Forestry Experiment Station Bulletins by an authorized administrator of The Research Repository @ WVU. For more information, please contact ian.harmon@mail.wvu.edu. 


\section{FOREST-LAND UTILIZATION}

IN

\section{NICHOLAS AND WEBSTER COUNTIES}

WEST VIRGINIA

by

E. C. WEITZELL

and

L. F. MILLER

WEST VIRGINIA AGRICULTURAL EXPERIMENT STATION

C. R. ORTON, Director MORGANTOWN

In Cooperation With The BUREAU OF AGRICULTURAL ECONOMICS UNITED STATES DEPARTMENT OF AGRICULTURE 
Digitized by the Internet Archive in 2010 with funding from Lyrasis Members and Sloan Foundation 


\title{
FOREST-LAND UTILIZATION
}

\section{IN \\ NICHOLAS AND WEBSTER COUNTIES \\ WEST VIRGINIA}

\author{
by \\ E. C. WEITZELL \\ and \\ L. F. MILLER
}

WEST VIRGINIA AGRICULTURAL EXPERIMENT STATION

C. R. ORTON, Director MORGANTOWN

In Cooperation With The

BUREAU OF AGRICULTURAL ECONOMICS

UNITED STATES DEPARTMENT OF AGRICULTURE 


\section{CONTENTS}

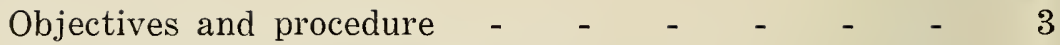

Nicholas and Webster counties - $\quad$ - $\quad-\quad 5 \quad-5$

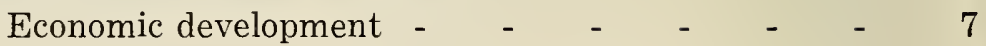

Agriculture and family living - _ _ _ $\quad$ - $\quad$ - 10

Character of three selected areas - $\quad$ - $\quad$ - $\quad$ - 11

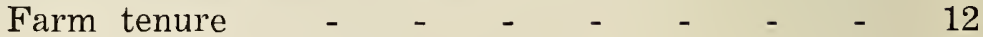

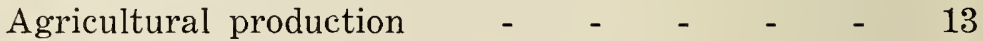

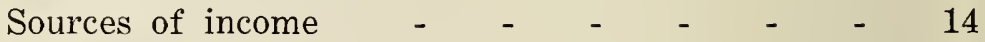

Non-farm income - $\quad$ - $\quad$ - $\quad$ - $\quad$ - $\quad$ - $\quad$ - 17

Problem of low incomes - $\quad$ - $\quad$ - $\quad$ - $\quad$ - 18

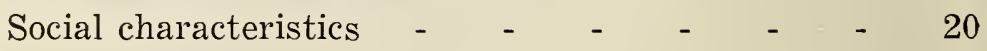

Ownership and taxation of forest lands $\quad$ - $\quad-\quad-\quad-23$

Farm and forest land tenure - $\quad$ - $\quad$ - $\quad$ - 23

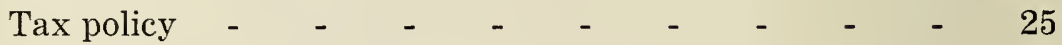

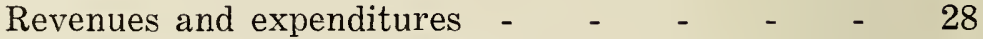

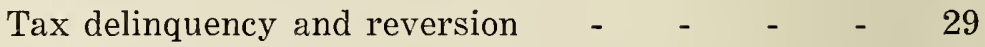

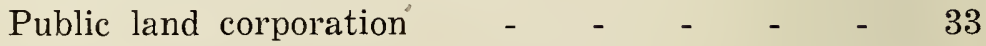

Forest production and policies - $\quad$ - $\quad$ - $\quad$ - $\quad$ - $\quad$ - 35

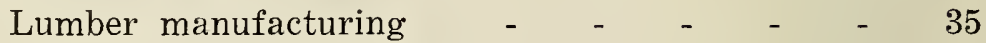

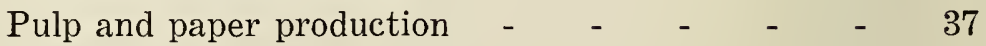

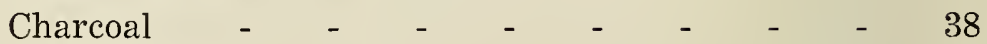

Other forest industries - $\quad$ - $\quad$ - $\quad$ - $\quad$ - 38

Forests in relation to coal mining - $\quad$ - $\quad$ - $\quad$ - 39

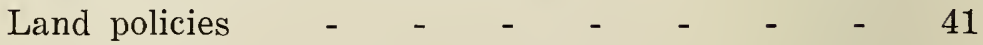

Forest resources and productivity $\quad$ - $\quad$ - $\quad$ - $\quad$ - $\quad$ - 42

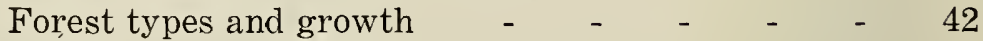

Feasibility of private forestry - $\quad$ - $\quad$ - $\quad$ - $\quad$ - 46

Employment and population adjustments - $\quad$ - 49

Feasibility of forest-farm homesteads - $\quad$ - $\quad-51$

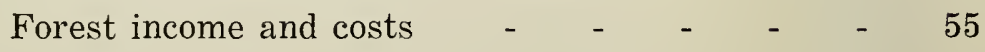

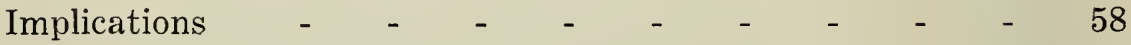

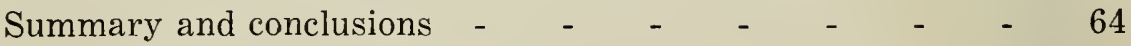




\section{Forest-Land Utilization}

\section{in \\ Nicholas and Webster Counties \\ West Virginia}

by E. C. Weitzell* and L. F. Miller†

THE FORESTS OF WEST VIRGINIA have been exploited in a manner I similar to that which has characterized the mining of certain subsurface resources. Little or no attention has been given to the development of a sustained forest industry. A relatively dense population that formerly depended on forest income and subsistence agriculture has been forced to find other employment, or live at a very low subsistence level. The disappearing forest industry and the lack of training and opportunities for employment in other areas have resulted in serious problems of social welfare in addition to problems of land and forest conservation.

Large tracts of land having no feasible use except forest production, combined with a relatively dense population dependent on the land resources, present problems of readjustment. It may be necessary to have adjustments in the man-land ratio, as well as adjustments in the methods of forest production and land use, if levels of income are to be acceptable. In order to raise the low level of living in forest areas where mining and other industries are not developed, without continuous public subsidies, there are two, or a combination of two, alternatives: (1) to develop forest operations of a type that will provide full employment for the people; and (2) to fit the people for and to provide alternative employment opportunities in this and other areas in order to relieve the subsistence pressure on land resources.

\section{OBJECTIVES AND PROCEDURE}

The specific objectives of this study were to (1) develop briefly the historical factors precipitating current problems; (2) find the relationship between prevailing subsistence farming and forest

\section{ACKYOWLEDGMENT}

The authors are especially grateful to Professor Torkel Holsoe, Forestry Division, West Virginia Agricultural Experiment Station, for his supervision and assistance in the collection and interpretation of the forestry data reported herein. Elmer Hallowell, Bureau of Agricultural Economics, assisted in obtaining and analyzing the fieln schedules concerning agriculture and family living. F. J. Marschner, Bureau of Agricultural Economics, assisted in the cartography. Others who have contributed to this research project include W. W. Armentrout, W. C. Perciral, and H. D. Erickson, West Virginia Agricultural Experiment Station. 
production as a background for possible future development; (3) indicate the character of the potential production of forest lands; (4) understand the relationship of the tenure pattern, and operating policies of land owners, to possible future developments; (5) determine the relationship of private and public interests, particularly the implications of local tax policy; (6) determine the feasibility of private and public land ownership relative to longtime forest management; and (7) appraise the possible need-for adjustment in the population. In this connection attention was given to the feasibility of developing forest-farm homesteads as a means of more fully utilizing land resources in the interests of greater social and economic welfare.

Nicholas and Webster Counties, West Virginia, were selected as representing conditions in the predominantly forested areas of the Southern Appalachians, where mining has followed the exploitation of virgin timber. The same counties were studied before 1930.1

Data on land ownership and taxation and on policies of large landowners and mill operators were collected on a county-wide basis. However, it was desirable to reduce the coverage for obtaining other more specific in-place data. Hence, three magisterial districts were selected within the two counties for intensive study. These districts were: (1) Hacker Valley in Webster County, representing forest predominance with little or no mining influence; (2) Hamilton in Nicholas County, representing the co-dominance of forestry and agriculture with rather strong mining influence; and (3) Wilderness in Nicholas County, in which appreciable acreages of land suitable for farming are available in the midst of large areas of forest land.

Within the three areas a sample was obtained by personal interview with every fourth household. Information was obtained regarding the family units and the sources and volume of income. For Hacker Valley District, ${ }^{2}$ present land use was mapped and a forest type classification made for the entire area. Stand densities, species, and growth rates were then obtained by sampling. Onemile cruise lines were chosen so as to represent all variations in topography, altitude, and forest types. On these lines, sample plots were chosen and the forestry data were obtained by trained foresters. To evaluate the feasibility of a specific type of forest-farm operating unit, a single small community, embodying a variation in the proportion of land suitable for farming was chosen. The limitations of these data must be recognized when considering similar problems in other parts of the region or other regions, less remotely located, and differing widely in physical, climatic, and economic environment.

1 Peck, M., et al., Economic Utilization of Marginal Lands in Nicholas and Webster Counties, W. Vo. U. S.'D. A. Tech. Bul. 303, 1932.

2 Owing to circumstances beyond control, it was not possibls to complete the land-use mapping and forest survey for the other two areas, as originally planned. 


\section{NICHOLAS AND WEBSTER COUNTIES}

Nicholas and Webster are adjoining counties in the Allegheny Plateau area of the Southern Appalachians, lying between federal highways 50 and 60 in central West Virginia (Fig. 1). The two counties are more or less representative of many portions of the Southern Appalachians, particularly those areas characterized by low-income farming, rapidly disappearing lumber operations, and recent extensive coal development. ${ }^{3}$

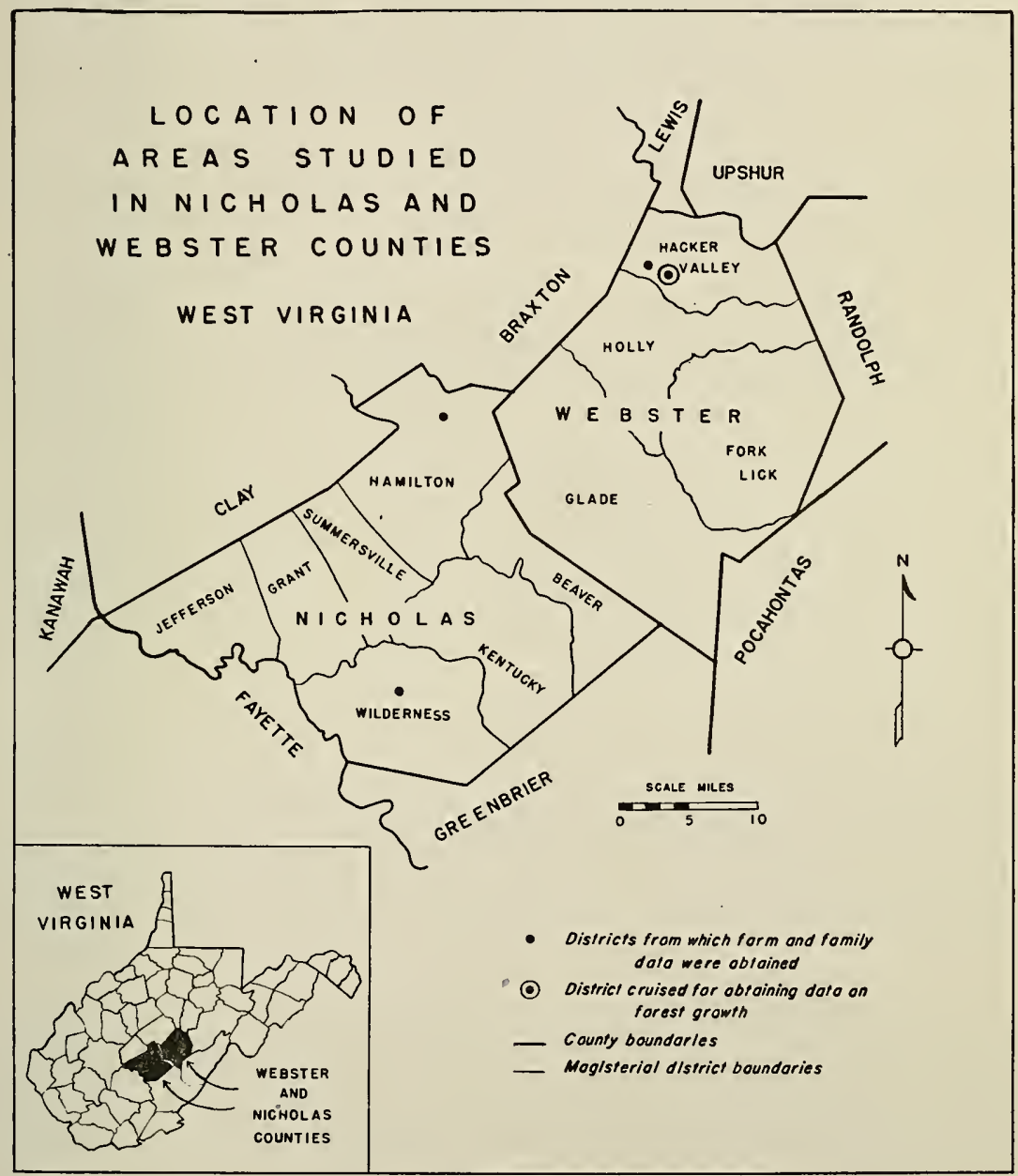

Figure 1

The surface of a major part of the two counties is sharply dissected, while a small portion of central Nicholas County and a small area near Cowen in Webster is more nearly rolling. These

3 Economic and Social Problems of the Sou'hern Appalachians. Bureau of Agricultural Economics, U. S. D. A. Misc. Pu'b. 205, 1935. 
latter areas include the only bottom land of any importance in the two counties. The extremely rough topography is indicated by the fact that three-fourths of all land in Webster County has a slope of more than 25 per cent. Two-fifths has a slope in excess of 40 per cent. 4 In fact, an appreciable acreage of cleared land in some sections of the area is on slopes of from 40 to 60 per cent.

A classification of the lands for the determination of use suitability, indicates only 6 per cent of the land in Nicholas and none in Webster as average cropland or better. On the other hand, more than 64 per cent of Nicholas and 95 per cent of Webster County is classified as suitable only for forest production. Much of this land is extremely rough and inaccessible. This classification, however, is not wholly realistic. Although. very little land is deemed suitable for commercial farming, a large number of self-sufficing farm units have utilized a comparatively large acreage for agricultural production.

The soils of this area were derived from sandstone and shale, and are thin on both steep and rolling terrain. The upland residual soils constitute about 97 per cent of all soils in the counties, and the Dekalb series is the only one of importance. ${ }^{6}$ About two-thirds of the residual soils are very stony, and in Webster approximately 22 per cent of all soils are unclassified "rough stony land." All the upland soils erode very rapidly when cultivated, and owing to the laborious and expensive process of replenishing fertility, little has been done in this respect. Complete destruction of cleared hillside soils has been prevented by the fact that only small patches are cultivated at a time and when left unbroken a quick cover of grass and brush protects the surface from severe erosion.

Alluvial or bottom soils constitute only 3 per cent of all lands in either county. Lack of drainage and the frequency of overflow discourage the cultivation of most of the narrow bottom soils. The forest soils are largely Dekalb stony loam. They are usually steep but comparatively productive and seem to have unusual ability to "come back," after being cleared, with a rapid growth of poplar and oak.

The climate of this section of the Appalachians is cool and temperate, with rather extreme temperature variations of short duration during both winter and summer. The growing seasons are usually short, varying around 4.5 months, depending on altitude and air drainage. Rainfall varies between 50 and 60 inches annually, being most intensive during late winter, spring, and early summer. Frequent heavy snows in winter make work in the forest a difficult task.

\footnotetext{
4 PohIman, G. G., Land Classification in West Virginia. W. Va. Agr. Exp. Sta. Bul. 284, p. 12, 1937.

5 Idem.
}

B Soil Surveys of Nicholas and Webster Counties, West Virginia. U. S. Department of Agriculture. 


\section{Economic Development ${ }^{\top}$}

Once the western portion of Augusta County, Virginia, during the colonial period, this region was principally hunting and trapping territory. Very soon after the Revolution, however, settlers began to establish themselves on the less rugged plateau portions of central Nicholas County. The area to the north (now Webster) was more rugged and remote, and was largely unsettled until the decade following the Civil War. Settlers were, in general, ScotchIrish and migrated from east of the ridges. This area of the state remained rather isolated until the early 1920's. The lack of any good roads and particularly of a connecting route north and south was a major factor in deterring development.

Aside from early hunting and trapping, self-sufficing farming was the major vocation of settlers until late in the 19th century. The relative inaccessibility to forests and minerals delayed the development of these resources. Following 1870, large lumber mills were established at Ronceverte and Sutton in bordering counties, and the large white pine and poplar logs were boomed down the Greenbrier and Elk rivers to be manufactured. Poplar veneer stock, and pine and poplar for export, were of major importance during this period.

It was not until 1889 that the first railroad was built to Richwood for removing the vast timber resources of this area. Immediately (1890) the Cherry River Boom and Lumber Company was established at that point. Expansion of the lumber industry progressed rapidly, with several other mills being located at neighboring points, during the three decades following 1900. The lumber industry first took only choice timber, but as resources were progressively depleted, operations became more intensive, until today practically "everything" is removed in the timbering process.

The comparative inaccessibility did not permit commercial mining of coals underlying Nicholas and Webster Counties until the decade preceding 1920. The war economy of 1939 to date has again made mining more profitable. Hence interest in land resources, both surface and subsurface, has increased, inasmuch as a large amount of timber is used in mining coal.

During 50 years (1890-1940) the lumber industry has developed from a wasteful exploitative process, taking only the very best and destroying much, to an intensive multiple-purpose industry which consumes practically everything cut, including the slabs. As the lumber industry declines, mining becomes even more important, yet dependent on forest supplies, and charcoal production takes what is left.

During this 50-year period the type of agriculture has not changed greatly from the self-sufficient type that was originally

7 R. L. Thompson, Webster County History, Excelsior Press, Webster Springs, W. Va., 1941. Older members of the present lumber firms operating in the counties gave additional background data. 
established. From Table 1, it is apparent that the number of farms increased during the period preceding 1900, but declined slightly during the two succeeding decades (to 1920). This can undoubtedly be attributed to a transfer of labor to lumbering, mining, and other non-farm pursuits. During the period from 1920 to 1930 the number of farms again increased, particularly tenant farms; and during the decade of 1930 the total number of farms increased 26 per cent in Nicholas and 54 per cent in Webster. The number of tenant farms doubled between 1930 and 1940. Although no data are available to indicate the process of obtaining new farms, it is recognized that they generally did not come about through subdivision of existing farms but rather by clearing small patches of new land, outside of commercial farming areas.

TABle 1-Trend in Farm Ownership and Tenancy, Nicholas and Webster Counties, West Virginia, 1880-1940

\begin{tabular}{|c|c|c|c|c|c|c|}
\hline \multirow{3}{*}{ Year } & \multicolumn{3}{|c|}{ NICHOLAS } & \multicolumn{3}{|c|}{ WEBSTER } \\
\hline & \multicolumn{3}{|c|}{ Average size and number of farms } & \multicolumn{3}{|c|}{ Average size and number of farms } \\
\hline & Size & Owners $^{1}$ & Tenants & Size & Owners ${ }^{2}$ & Tenants \\
\hline & Acres & Number & Number & Acres & Number & Number \\
\hline 1880 & 173 & 943 & 172 & 198 & 420 & 82 \\
\hline 1890 & 128 & 1279 & 180 & 136 & 673 & 94 \\
\hline 1900 & 109 & 1457 & 310 & 109 & 826 & 232 \\
\hline 1910 & 94 & 1407 & 263 & 101 & 864 & 220 \\
\hline 1920 & 92 & 1474 & 196 & 101 & 869 & 112 \\
\hline 1930 & 82 & 1449 & 351 & 85 & 935 & 169 \\
\hline 1940 & 67 & 1757 & 520 & 70 & 1285 & 415 \\
\hline
\end{tabular}

I Full or part owners.

It is further significant that the "average" size of farms has decreased steadily as the result of two major factors: (1) new farms have been very small; and (2) much of the woodland originally included in farms has been sold to commercial lumbering and mining interests. Some farms were established as part-time enterprises complementary to non-farm work, but in the main they are the result of an increase in the population which has not been provided with adequate employment in agriculture or industry. Although the acreage in farms decreased sharply about 1900, the proportion of "improved" farm land in Nicholas County advanced steadily from 26 per cent of the total land in farms (1880) to 54 per cent in 1920. The increase in Webster County was even more pronounced.

During the two decades following 1920, self-sufficing agriculture apparently was neglected in favor of non-farm employment. It was during this period that improved roads were constructed in these counties. Many people were employed in construction work; and as contact with the industrial areas became more feasible, many of the younger people left the hill farms. Cleared land was neglected and allowed to revert to brush. The local residents are conscious of the fact that public work relief and cash relief have 
deterred many families from "digging" a subsistence from the hill soils. Hence agriculture is on the decline in spite of the fact that the number of people living at least partially from the land has advanced greatly.

In accord with the decline in "improved" farm land, the acreage devoted to crops was reduced between 1920 and 1940 . The only crops that gained in importance during the period (1920 to 1940) were corn and potatoes. The causes of this were decidedly different. In the case of corn, the large increase in the number of subsistence farms was responsible for an expansion in the acreage of "corn patches" for producing basic human food. The expansion in the acreage of potatoes, on the other hand, was due to the interest of the more nearly commercial farmers in producing potatoes for sale.

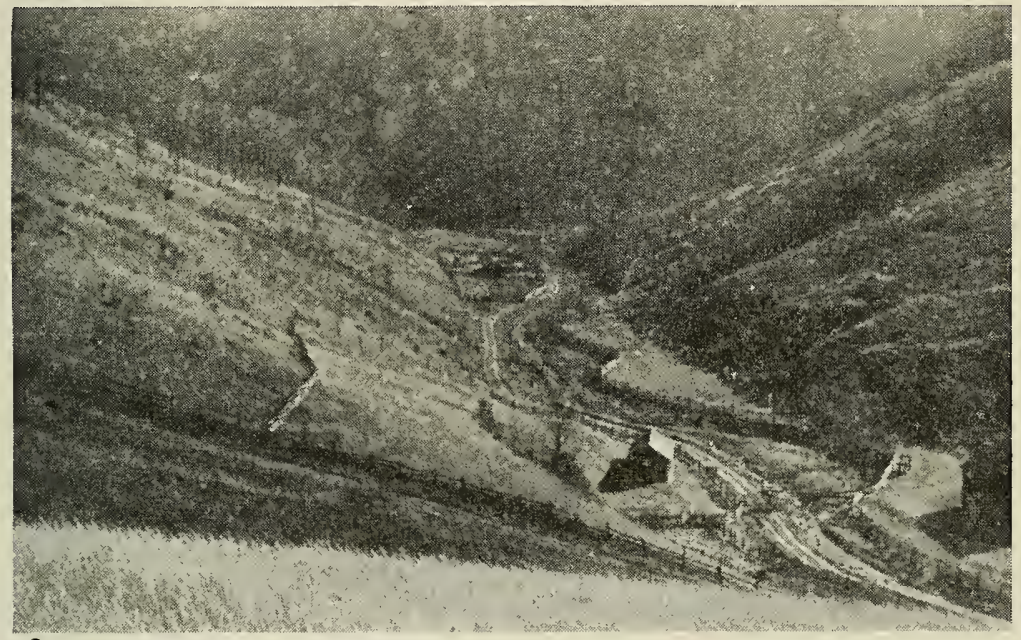

Figure 2. The rough topography is indicative of the character of hill farming. Shallow, stcep soils, rapid depletion, and severe erosion limit farming to a subsistence level.

The number of farm animals also decreased sharply from 1920 to 1940 , particularly sheep production, which was cut 48 per cent in Nicholas and 62 per cent in Webster. Although the pastures of this area are comparatively unsuited to cattle grazing, they are fair for sheep.

This declining trend in farm production is of particular significance when compared with the 30 per cent increase in the ruralfarm population in the same period. This means that there is a rapidly increasing need for non-farm sources of income.

Since the resources are largely suited to forestry and mining, it might be concluded that employment would follow the same pattern. However, data in Table 2 indicate two facts: (a) an appreciable number of people are dependent on submarginal farming and 
thus are underemployed; and (b) more than 3,000 employable workers (includes relief employment) are unemployed in the two counties. It is important to note that only 399 workers in Webster County are reported as being employed in agriculture (1940). Yet the census reports 1,700 farms for the county. This difference probably accounts lar'gely for the 1,600 workers reported as "seeking employment" and "employed on public relief."

TABLE 2-Labor Supply and Employment Pattern of Nicholas and Webster Counties, West Virginia, 1940

\begin{tabular}{|c|c|c|}
\hline \multirow{2}{*}{ EMPLOYMENT } & \multicolumn{2}{|c|}{ NUMBER OF MALE WORKERS ${ }^{1}$} \\
\hline & Nicholas & TVebster \\
\hline \multicolumn{3}{|l|}{ Total male population: } \\
\hline (14 years and older).. & ... 8,265 & 6,083 \\
\hline Total labor supply & $\ldots 6,276$ & 4,386 \\
\hline Employed ${ }^{2}$ & 4,851 & 2,703 \\
\hline Relief employment ................ & $\quad 517$ & 587 \\
\hline Seeking Work & 908 & 1,096 \\
\hline \multicolumn{3}{|l|}{ Employed in: } \\
\hline Agriculture & 1,962 & 399 \\
\hline Forest industry & 1,181 & 496 \\
\hline Coal mining & 565 & 948 \\
\hline Other & -.... 1,143 & 860 \\
\hline
\end{tabular}

1 Census of Population (Second Series) 1940.

2 Except public relief employment.

The relatively large number of men reported as unemployed, or under-employed, in the two counties is indicative of the low incomes and the meager subsistence living in the area. Recalling the unsuitable character of the land for agriculture and the declining forest industry, it is apparent that there is need for downward adjustments in population in so far as these factors are concerned. If coal mining continues to expand, perhaps large numbers of workers can be absorbed from the rural areas.

\section{AGRICULTURE AND FAMILY LIVING}

The agriculture of West Virginia varies from the several specialized types of farms in the limestone plateaus and the river valleys, to the low-income self-sufficing areas in the rugged mountainous sections. Nicholas and Webster counties are in the latter category, most of the farms being classified as self-sufficing, general livestock, and part-time. ${ }^{8}$

Slightly more than a third of the land area of Nicholas and Webster Counties is "farm land," the remaining two-thirds being owned as commercial forest. More than half of the farm land is woodland; and less than 5 per cent of all the land in Webster County is used for crops, compared with 8 per cent in Nicholas.

8 Armentrout, W. W. and Johnson, T. D., Types of Farming in West Virginia. W. Va. Agr. Exp. Sta. Bul. 292, 1939. 
Land clearing has almost ceased except where small patches are being cleared for the building of new houses. Most of the new home builders, however, clear only a small patch for corn adjacent to their two-room abode or settle on land already cleared. The net result is a decrease in improved land, owing to a reversion of old lands to forest cover at a more rapid rate than land is being cleared.

Approximately 53 per cent of all farms in the two counties have an average of less than six acres of cropland, and many have only three acres. This limitation in land resources is a severe handicap in obtaining a living by farming. The few larger farms having from 20 to 40 acres of cropland are situated along the larger streams or in the small plateau areas from Cowen to Craigsville and Summersville. There is little or no tendency to subdivide these larger farms.

Approximately 77 per cent of all farmers own all or part of the land they operate. A small number of owners are renting additional acreages to enlarge their operating units slightly. The 935 tenants include a large number of squatters who have cleared small patches within the boundaries of commercial woodlands. Technically, most of them are bona fide tenants because they have been placed under contract, in order to protect the property rights of the owner. The number of both owners and tenants advanced sharply during the decade following 1930. Tenancy increased 51 per cent in Nicholas and 156 per cent in Webster County. The greatest increase in tenancy took place during the early years of the depression, when this area experienced a damming up of local youth having no outside opportunities. Since then, many have become owners of small plots for which they have bargained to pay from $\$ 150$ to $\$ 500$. These units have been established along the hard roads-most of the more recent builders being local young people who are depending on non-farm employment and relief. There has been no migration from the outside.

\section{CHARACTER OF THREE SELECTED AREAS}

The three areas selected for intensive study represent variations in the dependence of the people on agriculture, mining, forestry, and relief employment. Data for these areas were obtained by personal interview with every fourth household. These data are presented in some detail to illustrate the character of resource utilization and of family living in this portion of the Appalachians. It was originally intended to obtain detailed forestry data from all three sample areas. As already indicated it was found necessary to limit the forestry survey to one area-Hacker Valley. The survey of Agriculture and Family Living is presented for the three areas, however, to illustrate variations in the relationship of farming to forestry and non-farm employment as well as the character of rural living and enterprise. 


\section{Farm Tenure}

Squatters and tenants lack direct access to forest resources, and under present extensive methods of operation, employment is very low. Any proposed system for forest and farming combinations in the three sample areas must give consideration to the fact that 31 per cent of all operators are tenants and 8 per cent are squatters. These people must be provided with adequate land of their own, or be given employment in the larger holdings or in woodprocessing plants if complete utilization of available labor is to be obtained.

Owner-operated farms were larger and had more cropland than tenant and squatter farms. Owners' total agricultural sales, forest products sales excluded, averaged from two to five times as high as such sales by tenants (Table 3). Squatters had very little cash income from agricultural sales. Tenants and squatters depend to a greater extent on non-farm employment.

The average gross value of perquisites on owner-operated farms exceeded that of perquisites on tenant farms by $\$ 29, \$ 92$, and $\$ 83$ in areas one, two, and three, respectively. In other words, there was an apparent relationship between tenure status and the value of the products obtained for home use from the farm. However, rather than being a result of tenure or of leasing arrangement, this fact is largely the result of the quality of land available, size of farm business, choice of employment, and perhaps the attitude and ability of the operator.

In general, owners realized a much higher gross family income, including perquisites, than did tenants and squatters. Non-farm labor and relief provided more than half the gross incomes of all tenure groups, with the exception of owners in areas one and three. Relief provided one-fourth of the gross incomes of all tenure groups in area one, less than one-eighth of the income of any tenure group in area two, and less than one-twentieth of the income of any group in area three, where a larger percentage of the land was suitable for farming.

TABLE 3-Character of Tenure in Three Sample Areas, Nicholas and

Webster Counties, West Virginia ${ }^{1}$

\begin{tabular}{l|c|c|c|c|c|c}
\hline Tenure & Area $^{2}$ & $\begin{array}{c}\text { Number } \\
\text { of } \\
\text { farms }\end{array}$ & $\begin{array}{c}\text { Years on } \\
\text { present } \\
\text { farm }\end{array}$ & $\begin{array}{c}\text { Acres } \\
\text { cropland } \\
\text { per farm }\end{array}$ & $\begin{array}{c}\text { Farm } \\
\text { income } \\
\text { (Average) }\end{array}$ & $\begin{array}{c}\text { Non-farm } \\
\text { income } \\
\text { (Average) }\end{array}$ \\
\hline Owners $^{1}$ & 1 & 53 & 20.9 & 13.8 & $\$ 156$ & $\$ 347$ \\
& 2 & 37 & 21.2 & 14.3 & 144 & 597 \\
Renters & 3 & 69 & 24.0 & 17.0 & 247 & 432 \\
& 1 & 21 & 7.0 & 7.5 & 44 & 397 \\
Squatters & 2 & 17 & 2.6 & 6.9 & 80 & 903 \\
& 3 & 16 & 8.8 & 6.6 & 61 & 402 \\
& 1 & 10 & 5.7 & 6.0 & 12 & 300 \\
& 2 & 8 & 5.3 & 5.6 & 38 & 441 \\
\hline
\end{tabular}

4 Includes part-owners. 


\section{Agricultural Production}

The acreage of cropland per farm was one of the most important factors controlling farm income in the three areas. Thirty to 40 per cent of the farms in all three areas had less than 9 acres of cropland in 1940, excluding those units which did not meet the census definition of a farm. Approximately one-third of the farms in the three areas had between 9 and 18 acres of cropland and about one-eighth had over 26 acres apiece. The farms having between 18 and 27 acres of cropland varied from 5 per cent, in area two, to 23 per cent in area three. Farms having the larger crop acreages also had the highest average acreages of pasture and woodland, although the small farms had a higher proportion of their total area in forest land than the larger ones.

Data on crop yields and sales of farm products showed that the small farms were operated no more intensively than the large ones, inasmuch as both groups depended largely on extensive livestock enterprises. Major readjustments both in land use and in organization would be necessary before these small farmers could hope to attain significantly larger incomes. In many cases, not enough cropland is available for even a subsistence unit.

In terms of acreage planted, corn was the most important crop on all except the largest farms. On the latter, the acreage of hay exceeded that of corn. The non-farm operators averaged about a fifth of an acre of corn each. Small-grain acreage was roughly the same as that of corn on the larger farms but was negligible on the smaller farms (Table 4). Crop yields were uniformly low in the three areas because of poor soil and management practices. Little lime or fertilizer was used and tillage was still done largely by hand methods.

TABLE 4-Crop and Pasture Land on Farms in Three Sample Areas.

Nicholas and Webster Counties, West Virginia, 1940

\begin{tabular}{|c|c|c|c|c|c|c|c|c|}
\hline \multirow{2}{*}{$\begin{array}{l}\text { Acreage } \\
\text { cropland }\end{array}$} & \multirow[b]{2}{*}{ Area } & \multicolumn{7}{|c|}{ AVERAGE ACREAGE PER FARM } \\
\hline & & Total & $\begin{array}{c}\text { Cropland } \\
\text { (total) }\end{array}$ & Corn & $\begin{array}{l}\text { Small } \\
\text { grain }\end{array}$ & Hay & $\begin{array}{c}\text { Pasture } \\
\text { (improved) }\end{array}$ & $\begin{array}{c}\text { Forest } \\
\text { and other }\end{array}$ \\
\hline \multirow{3}{*}{$\begin{array}{l}0-3 \\
(\text { non-farm })^{1}\end{array}$} & 1 & 1.1 & 0.4 & 0.3 & 0 & 0 & 0 & 0.7 \\
\hline & 2 & 0.8 & 0.3 & 0.1 & 0 & 0 & 0 & 0.5 \\
\hline & 3 & 1.2 & 0.5 & 0.2 & 0 & 0 & 0 & 0.4 \\
\hline \multirow{3}{*}{$\begin{array}{c}0-8 \\
(\text { farm })\end{array}$} & 1 & 68.0 & 3.9 & 2.4 & 0.2 & 1.0 & 13.1 & 51.0 \\
\hline & 2 & 42.3 & 4.5 & 3.2 & 0.2 & 0.6 & 7.3 & 30.5 \\
\hline & 3 & 31.1 & 3.3 & 1.7 & 0.4 & 0.4 & 9.1 & 18.7 \\
\hline \multirow[t]{3}{*}{$9-16$} & 1 & 97.0 & 12.4 & 4.9 & 0.8 & 6.0 & 21.8 & 62.8 \\
\hline & 2 & 87.0 & 12.4 & 5.2 & 1.1 & 5.5 & 21.0 & 53.6 \\
\hline & 3 & 55.0 & 13.1 & 5.2 & 3.9 & 2.6 & 12.3 & 28.6 \\
\hline \multirow[t]{3}{*}{$17-25$} & 1 & 116.0 & 21.1 & 5.2 & 2.1 & 13.3 & 30.3 & 64.5 \\
\hline & 2 & 92.0 & 24.0 & 11.6 & 5.0 & 6.0 & 27.0 & 41.0 \\
\hline & 3 & 77.0 & 22.6 & 5.3 & 8.8 & 6.3 & 14.8 & 39.6 \\
\hline \multirow[t]{3}{*}{26 and over } & 1 & 228.0 & 35.5 & 6.3 & 4.6 & 24.4 & 49.8 & 142.7 \\
\hline & 2 & 136.0 & 32.8 & 8.0 & 3.6 & 20.0 & 38.0 & 65.2 \\
\hline & 3 & 177.0 & 40.9 & 7.8 & 15.1 & 15.2 & 54.2 & 8.9 \\
\hline
\end{tabular}


Livestock was the most important farm enterprise in the sample areas, both as a source of cash farm income and for family maintenance. Livestock and livestock products accounted for about a fifth of the gross farm income, including perquisites on the small farms, and 45 per cent of the total on the larger farms (Table 5).

TABLE 5-Character of Livestock Production According to the Acreage of Cropland, Nicholas and Weßster Counties, West Virginia, 1940

\begin{tabular}{|c|c|c|c|c|c|c|c|}
\hline \multirow{2}{*}{$\begin{array}{c}\text { Acreage } \\
\text { cropland }\end{array}$} & \multirow{2}{*}{ Area } & \multicolumn{5}{|c|}{ AVERAGE NUMBER OF HEAD } & \multirow{2}{*}{$\begin{array}{l}\text { Number } \\
\text { of farms }\end{array}$} \\
\hline & & Cows & Horses & Hogs & Sheep & Hens & \\
\hline $0-3$ & 1 & .8 & 0 & .8 & 0 & 12 & 5 \\
\hline \multirow{2}{*}{ (non-farm) } & 2 & .5 & 0 & .4 & 0 & 8 & 16 \\
\hline & 3 & .4 & 0 & .3 & 0 & 7 & 15 \\
\hline $0-8$ & 1 & 1.0 & .2 & 1.0 & 1.3 & 14 & 38 \\
\hline \multirow{2}{*}{ (farm) } & 2 & 1.0 & .5 & .7 & .3 & 15 & 35 \\
\hline & 3 & .8 & .2 & .9 & .9 & 10 & 30 \\
\hline \multirow[t]{3}{*}{$9-16$} & 1 & 1.9 & .8 & 2.0 & 2.6 & 31.7 & 27 \\
\hline & 2 & 1.9 & .8 & 2.0 & 4.5 & 24.0 & 16 \\
\hline & 3 & 1.6 & .8 & 2.6 & 2.7 & 22.3 & 26 \\
\hline \multirow[t]{3}{*}{$17-25$} & 1 & 3.0 & 1.1 & 2.5 & 9.2 & 52.1 & 9 \\
\hline & 2 & 2.3 & 2.6 & 5.3 & 8.6 & 23.0 & 3 \\
\hline & 3 & 2.7 & 1.7 & 3.5 & 6.5 & 46.0 & 19 \\
\hline \multirow[t]{3}{*}{26 and over } & 1 & 4.4 & 2.2 & 3.2 & 12.9 & 55.0 & 10 \\
\hline & 2 & 3.6 & 2.3 & 3.7 & 4.5 & 40.0 & 8 \\
\hline & 3 & 7.0 & 2.6 & 13.1 & 19.1 & 51.2 & 10 \\
\hline
\end{tabular}

This variation in the relative importance of livestock sales was due to the fact that home consumption becomes less important in relation to the total farm business as the size of the business increases. Livestock and livestock products accounted for 60 per cent of the value of all food produced for home consumption in the three areas. Practically every farm in the area had one or more cows and a few hens, about two-thirds of the farms reported one or more hogs, and a little over half the farms had one or more horses. A third of the farms in area one, 17 per cent of those in area two, and 42 per cent of those in area three, reported sheep, but the flocks were very small. Area three had the highest percentage of farms reporting hogs, sheep, and hens.

\section{Sources of Income}

The production of food for home consumption was the most important part of the farm enterprise on farms having less than 16 acres of cropland." On farms having larger crop acreages, the sales of livestock and livestock products were of about the same importance as the production of perquisites. Farms having over 26 acres of cropland provided almost three times as much food for home consumption as did farms in the lowest brackets. Table 6

8 The value of perquisities excludes summer vegetables used directly from gardens, and rent for dwelling. All other items were derived by applying uniform farm prices to quantities obtained on schedules. 
shows that there was an appreciable increase in the value of perquisites with each increase in the acreage of cropland in all three areas.

Dairy products, the most important item of home consumption, represented one-third the value of all perquisites. Each of the following groups of items of home production constituted from 13 to 17 per cent of the gross value of all perquisites: canned fruit and vegetables, poultry and poultry products, potatoes, and pork. Cornmeal was consumed in comparatively large quantities but its monetary value was so low that it represented but 5 per cent of the total value of all perquisites.

Cash income from farm sources was extremely small on farms having less than 16 acres of cropland. Beef cattle and poultry contributed most of the cash income on the larger farms. Cash crops were unimportant, except for the comparatively few farmers producing potatoes on a commercial scale, and most of these were located in the central portion of the two-county area.

TABLE 6-Sources of Gross Farm Income in Three Sample Areas, Nicholas and Webster Counties, West Virginia, 1940

\begin{tabular}{|c|c|c|c|c|c|c|}
\hline \multirow{2}{*}{$\begin{array}{l}\text { Acreage } \\
\text { cropland }\end{array}$} & \multirow{2}{*}{ Area } & \multicolumn{5}{|c|}{ AVERAGE AMOUNT (DOLLARS) OF INCOME } \\
\hline & & Crops & Livestock $^{1}$ & Perquisites 2 & Forest $^{3}$ & Total \\
\hline $\begin{array}{l}0-3 \\
(\text { non-farm) }\end{array}$ & $\begin{array}{l}1 \\
2 \\
3\end{array}$ & $\begin{array}{l}1 \\
1\end{array}$ & $\begin{array}{r}10 \\
6 \\
13\end{array}$ & $\begin{array}{r}105 \\
48 \\
77\end{array}$ & $\begin{array}{c}\ldots . . \\
\cdots \cdots \\
\cdots \cdots\end{array}$ & $\begin{array}{r}115 \\
55 \\
91\end{array}$ \\
\hline $\begin{array}{c}0-8 \\
(\text { farm })\end{array}$ & $\begin{array}{l}1 \\
2 \\
3\end{array}$ & $\begin{array}{r}2 \\
5 \\
10\end{array}$ & $\begin{array}{l}31 \\
44 \\
47\end{array}$ & $\begin{array}{l}149 \\
176 \\
125\end{array}$ & $\begin{array}{r}2 \\
17 \\
13\end{array}$ & $\begin{array}{l}184 \\
242 \\
195\end{array}$ \\
\hline $9-16$ & $\begin{array}{l}1 \\
2 \\
3\end{array}$ & $\begin{array}{r}1 \\
17 \\
58\end{array}$ & $\begin{array}{l}85 \\
94 \\
82\end{array}$ & $\begin{array}{l}227 \\
244 \\
224\end{array}$ & $\begin{array}{r}31 \\
43 \\
8\end{array}$ & $\begin{array}{l}344 \\
398 \\
372\end{array}$ \\
\hline $17-25$ & $\begin{array}{l}1 \\
2 \\
3\end{array}$ & $\begin{array}{r}13 \\
3 \\
82\end{array}$ & $\begin{array}{l}336 \\
214 \\
244\end{array}$ & $\begin{array}{l}238 \\
317 \\
325\end{array}$ & $\begin{array}{r}114 \\
11\end{array}$ & $\begin{array}{l}587 \\
648 \\
662\end{array}$ \\
\hline 26 and over & $\begin{array}{l}1 \\
2 \\
3\end{array}$ & $\begin{array}{r}27 \\
37 \\
130\end{array}$ & $\begin{array}{l}311 \\
323 \\
509\end{array}$ & $\begin{array}{l}353 \\
355 \\
405\end{array}$ & $\begin{array}{r}75 \\
6 \\
41\end{array}$ & $\begin{array}{r}766 \\
721 \\
1,085\end{array}$ \\
\hline
\end{tabular}

2 Excludes the value of summer vegetables used directly from garden because of the difficulty in obtaining reliable data, and rent for dwelling.

3 Only a few farmers reported income from forests-most of it represents tie or saw timber boundaries sold for clear-cutting. Few people sold pulp.

The most serious dietary deficiency apparently was a lack of meat and green vegetables, particularly during the winter. Fresh green vegetables are unknown in winter, except to the few households which bury cabbage for winter use. Meat consumption is limited to a very small supply of home produced pork and poultry. A majority of the farms in the area spent less than $\$ 1$ per month for meat. An appreciable number of families in areas one and two were without milk for a considerable part of the year. Although most of the units having more than three acres of cropland owned 
at least one cow and a few chickens, the amount and quality of feed was low. Consequently, production was light and many families lacked adequate supplies of these products.

It is true that production, for home consumption in particular, could be greater, even on the limited land available. The abundant labor supply could provide much more adequate diets from home gardens if a number of obstacles were removed. In fact, many families do grow a reasonable supply of summer vegetables; and the brush lands usually supply wild berries and fruits.

The obstacles to a better "live-at-home" program are several. Lack of techniques and knowledge is a serious handicap to most of these people. This might be partially overcome by education and supervision. On the other hand, most families are getting farther away from a subsistence type of living from the soil. They lack the drive to prepare and maintain the steep, rugged land. The large acreage of land that has been abandoned in recent years is evidence. They prefer "public work." Although inertia may be a major obstacle, most of the younger people are continually seeking better opportunities. Training for and contact with available employment are the things they need most.

The rural non-farm residents of the three areas depend upon mining, relief, and forest industry for a large share of their incomes. Their "farming" consists of planting a garden and sometimes a small patch of corn; and in a few cases, of raising a cow, a hog, and a few chickens for home use. Perquisites equal from twothirds to four-fifths the value of gross "farm income" received by the non-farm group (less than three acres), but the production of food for home use is small for numerous families.

A very small proportion of the farmers in the three areas sold wood products during 1940 or the three years previous to that date (Table 7). Total sales of timber and timber products during 1940 amounted to but 3 per cent of the gross farm and non-farm income in area one, the most heavily forested area, and the one in which forest product sales were largest.

Table 7-Total Forest Product Sales by Farmers in Three Sample Areas,

Nicholas and Webster Counties, West Virginia, 1939-1940

\begin{tabular}{|c|c|c|c|c|c|c|c|}
\hline \multirow{2}{*}{ Product } & \multirow{2}{*}{ Year } & \multicolumn{2}{|c|}{ HACKER VALLEY } & \multicolumn{2}{|c|}{ NORTH HAMILTON } & \multicolumn{2}{|c|}{ WILDERNESS } \\
\hline & & Value & No. reporting & Value & No. reporting & Value & No. reporting \\
\hline Timber & $\begin{array}{l}1939 \\
1940\end{array}$ & $\$ \ldots \ldots$ & 4 & $\begin{array}{r}\$ 890 \\
786\end{array}$ & $\begin{array}{l}2 \\
3\end{array}$ & $\begin{array}{r}\$ 494 \\
390\end{array}$ & $\begin{array}{l}4 \\
4\end{array}$ \\
\hline $\begin{array}{l}\text { Ties and } \\
\text { Props }^{1}\end{array}$ & $\begin{array}{l}1939 \\
1940\end{array}$ & $\begin{array}{r}79 \\
182\end{array}$ & $\begin{array}{l}3 \\
2\end{array}$ & $\begin{array}{l}247 \\
871\end{array}$ & $\begin{array}{l}5 \\
7\end{array}$ & $\begin{array}{l}128 \\
300\end{array}$ & $\begin{array}{l}3 \\
2\end{array}$ \\
\hline Pulpwood & $\begin{array}{l}1939 \\
1940\end{array}$ & 157 & $\dddot{4}$ & $\ldots \ldots$ & $\cdots$. & $\begin{array}{l}119 \\
678^{1}\end{array}$ & $\begin{array}{r}2 \\
12\end{array}$ \\
\hline
\end{tabular}




\section{Non-Farm Income}

Non-farm income exceeded the combined value of agricultural sales, forest product sales, and perquisites in each of the three areas. Such income amounted to from 53 per cent of gross income in area one to 69 per cent in area two. Non-farm income (Table 8) was approximately two times as great as farm income (Table 6) on the group of farms with less than eight acres of cropland.

Almost two-fifths of all families in the three areas received relief of one type or another during 1940 (60 per cent in area one, 32 per cent in area two, and 24 per cent of those in area three). It was indicated that the WPA was the most important source of outside income to all operators in area one, with the exception of farmers having over 26 acres of cropland. In the other areas, only the nonfarm groups and those farmers having less than 9 acres of cropland reported income from WPA.

About 10 per cent of the households received income from Old Age Assistance and direct relief. Other families received aid for dependent children, from veterans' pensions, and from boys in the CCC. A large number received "surplus commodities," but it was impossible to calculate the value of the commodities received. A large proportion of the families receiving direct relief, old-age pensions, aid for dependent children, and veterans' pensions will always be dependent upon outside assistance because the heads of the families are either deceased, physically ill, or mentally defective.

TABLE 8-Sources of Non-farm Income to Families of Three Sample Areas, Nicholas and Webster Counties, West Virginia, 1940

\begin{tabular}{|c|c|c|c|c|c|c|c|c|}
\hline \multirow{2}{*}{$\begin{array}{l}\text { Acreage } \\
\text { cropland }\end{array}$} & \multirow[b]{2}{*}{ Area } & \multicolumn{7}{|c|}{ AVERAGE AMOUNT (DOLLARS) OF INCOME } \\
\hline & & Forests & Mines & $\begin{array}{l}\text { Farm } \\
\text { labor }\end{array}$ & WPA & $\begin{array}{l}\text { Other } \\
\text { relief }^{1}\end{array}$ & Other $^{2}$ & Total \\
\hline $0-3$ & 1 & 170 & 0 & 19 & 212 & 0 & 147 & 548 \\
\hline \multirow{2}{*}{ (Non-farm) } & 2 & 13 & 459 & 21 & 80 & 74 & 46 & 693 \\
\hline & 3 & 307 & 353 & 3 & 21 & 14 & 14 & 712 \\
\hline \multirow{3}{*}{$\begin{array}{c}0-8 \\
(\text { Farm })\end{array}$} & 1 & 64 & 79 & 14 & 155 & 84 & 8 & 404 \\
\hline & 2 & 82 & 210 & 17 & 96 & 21 & 32 & 458 \\
\hline & 3 & 55 & 194 & 14 & 48 & 43 & 127 & 481 \\
\hline \multirow[t]{3}{*}{$9-16$} & 1 & 87 & $\ldots \ldots$ & 8 & 115 & 77 & 74 & 361 \\
\hline & 2 & 60 & 62 & 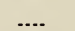 & ........ & 8 & 246 & 376 \\
\hline & 3 & 68 & 355 & 5 & $\cdots$. & 33 & 98 & 559 \\
\hline \multirow[t]{3}{*}{$17-25$} & 1 & 32 & 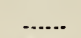 & 4 & 109 & 46 & 2 & 193 \\
\hline & 2 & 47 & 220 & 30 & ........ & .... & 7 & 304 \\
\hline & 3 & 135 & 34 & $\cdots$. & -...... & 13 & 179 & 361 \\
\hline \multirow[t]{3}{*}{26 and over } & 1 & 161 & ........ & 14 & ....... & $\ldots$ & 130 & 305 \\
\hline & 2 & 25 & . & .... & ........ & .... & 51 & 76 \\
\hline & 3 & ........ & 273 & .... & ........ & 1 & 179 & 453 \\
\hline
\end{tabular}

2 Includes school teaching, work for county, and work out of county not otherwise classified. 
Approximately 46 per cent of the WPA workers were men under 40 years of age. Only a few men on WPA had physical deficiencies which would prevent them from engaging in other occupations. During the war emergency in particular, and in behalf of a higher level of living over a longer period, it would seem that this labor supply might be more productively employed in connection with industry or commercial agriculture in other areas. Many of these men should probably be trained and encouraged to seek more lucrative employment, rather than endeavor to rehabilitate the extremely low quality land on which they are now located.

\section{Problem of Low Incomes}

The foregoing analysis indicates very low incomes from agricultural sources on a majority of the farms. On the other hand, a significant proportion received an appreciable amount of non-farm income. It remains now to determine the extent to which gross incomes of rural families are inadequate to maintain a reasonable level of health and welfare.

Data in Table 9 indicate two major facts: (1) more than 62 per cent of all families in the three sample areas receive total cash incomes of less than $\$ 500$, the amount which might be judged adequate to permit a desirable level of health and welfare; and (2) a majority of the families do not have enough land suitable for crops to supply reasonable incomes from farming.

In the interest of social welfare it seems pertinent to conclude that not more than 40 per cent of the 1941 population of the area found adequate work opportunities. This is important from the standpoint of the adults, but still more important in terms of the children involved. Translating the data from this one-fourth sample into terms of totals, approximately 1,400 children under the age of 18 years are being reared in families receiving total cash incomes of less than $\$ 500$, exceeding relief, within the three small areas. The problem of rehabilitation depends largely on the ability of the male heads of families to adapt themselves to employment opportunities, either within the immediate vicinity or in some other location. 


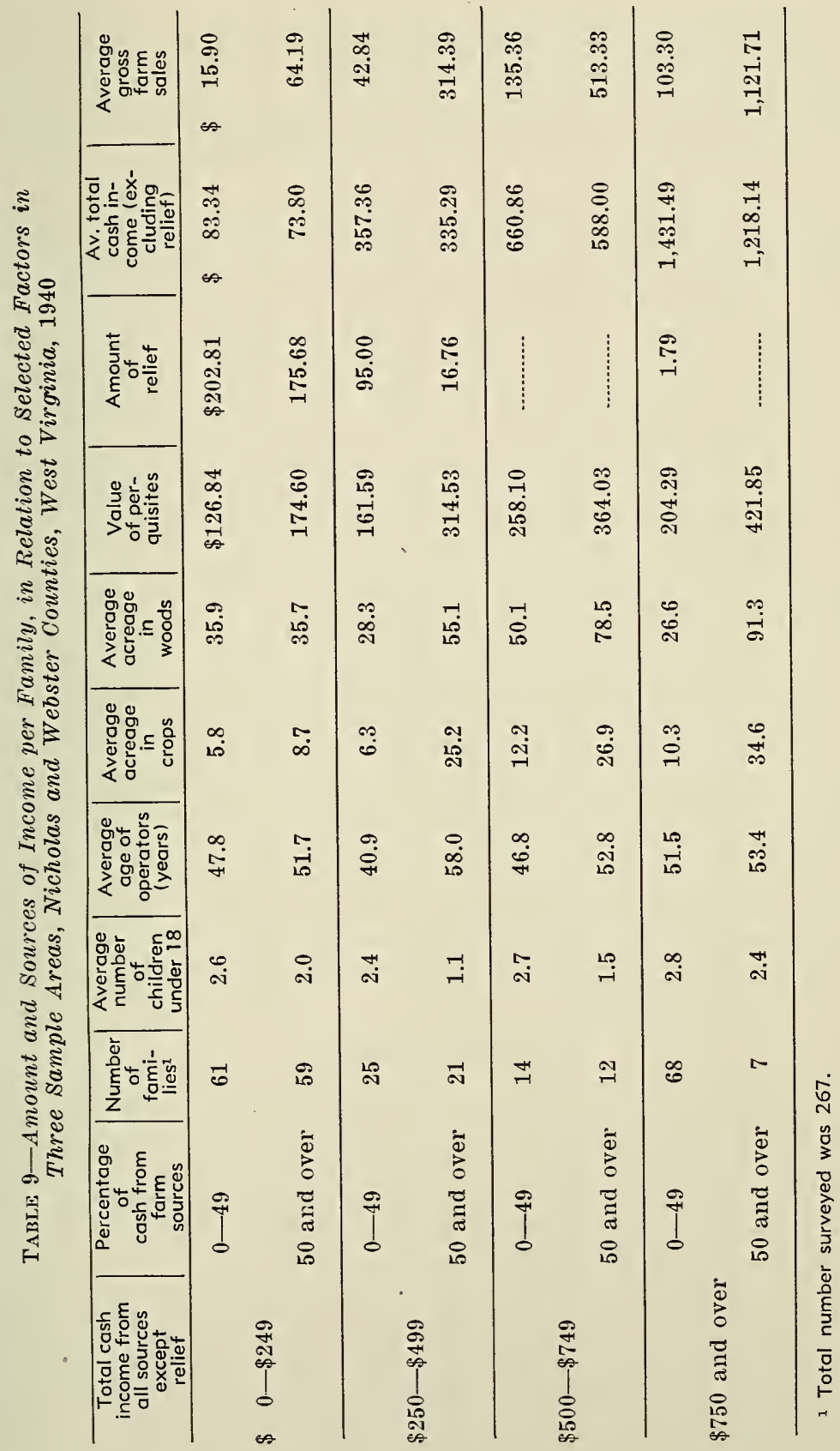


Over one-fourth of all heads of households in the three areas had passed the age of 60. A large part of this group was either dependent upon Old Age Assistance (29\%) or upon adult children for support, and cannot be considered as part of the available labor force. In addition 17 per cent of the farmers under the age of 60 in the three areas were partially incapacitated by physical ailments.

Of the 156 male family heads receiving gross cash incomes of less than $\$ 500,82$ were under the age of 50 , and 49 were under 40 years of age. In the families of those under 50 were 276 children under 18 years of age. Transposed in terms of all families in the three areas, there were approximately 328 families, including more than 1,100 children, with family heads under 50 years of age, that were living at a subsistence level. Most of these families would have much higher earning ability if relocated or provided with more adequate employment opportunities within the area. Minor physical ailments would limit the adaptability of some workers, but most of the health deficiencies are judged to be curable.

In addition to those under 50 years old, there were 74 family heads over 50 years of age receiving gross cash incomes of less than $\$ 500$. In contrast to an average age of 37 years for those under 50 , those over 50 averaged 62 years. Those in the latter group possess little potential adaptability for employment. Many exceptions might be found, but in general, physical infirmities would limit the employment of persons in this age group. On the other hand, more than 330 children were dependent on family heads over 50 years of age, and gross cash incomes of less than $\$ 500$, in the three areas. This fact is of major social concern. In order to foresee a possibility for these children to achieve a reasonable and acceptable level of living, they must have adequate education and training for future employment opportunities. With the present educational system, and the limitations of incomes, they do not have access to such training.

\section{Social Characteristics}

There was a considerable migration to industrial areas during the decade following 1920, but lack of opportunities for work has caused many older children to settle down near their parents. Thus, it is not unusual to find a group of four or five families of the same name, all blood relatives, living in small makeshift cabins on isolated and low quality land.

Isolation had not prevented many of the people from moving around in search of better lands to farm and in search of non-farm employment. Thus, more than 55 per cent of the squatters and tenants had moved within the past five years, while only 18 per cent of the owners had moved within that time. Almost two-fifths of those who had moved claimed to have done so to obtain better farms. Most of the moves were from one low-quality farm to another within the same locality. Very few occupants of the three 
areas had ever worked at industrial occupations outside of Nicholas and Webster Counties. Apparently, there were few living in the counties (1941) who had come "back to the land" from the cities as a result of the 1930 depression. Although tenants and squatters moved more frequently than owners, they had the same tendency to remain relatively close to their parental homes.

Many operators had received little formal education and vocational training has been unavailable to most people. Seven per cent of the heads of families had received no schooling and an additional 40 per cent had progressed no further than the fifth grade.

If long-time plans for the better utilization of the land resources of the area are to be effective, the education and training of the younger generation is paramount. Since almost 40 per cent of the present families' mature children have settled within the counties and since there is little immigration to the areas, it is apparent that children of present residents will constitute a large proportion of the area's future population. While lack of employment opportunities has caused a backing up of the young people on the farms (one-fourth of all operators' sons over 18 years of age are living at home), 19 per cent of operators' adult sons have left the state and are employed in industry and in the service trades.

Families were largest in area one, the most isolated area of the three and the area in which gross income per family was the smallest. Almost 20 per cent of the families in that area had nine or more members, while only 6 per cent of the families in the best agricultural area were that large.

TABLE 10-Children at Home by Age Groups in Three Areas, Nicholas and Webster Counties, West Virginia, $1940^{1}$

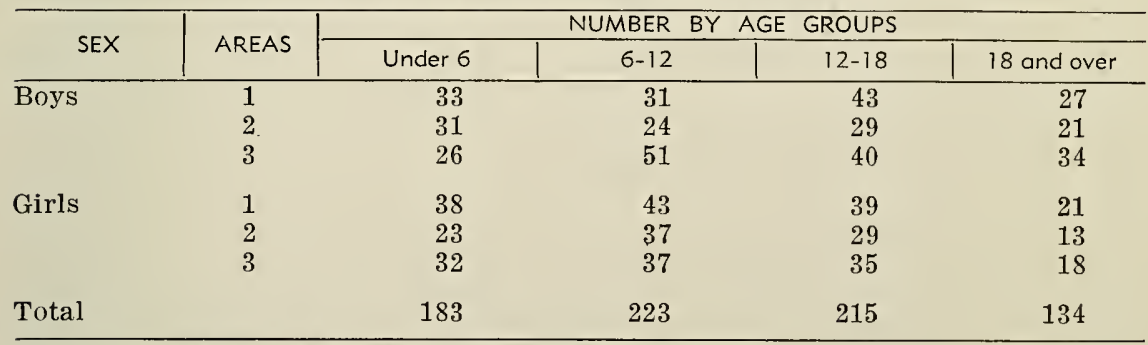

1 Data represent the children of 267 families.

A large majority $(76 \%)$ of the elementary students attend one-room schools within walking distance of their homes. The average daily attendance in these schools was 84 per cent of the enrollment for the three areas. According to attendance officers, a large portion of this absence is due to low family income and consequent illness, lack of shoes and clothing, and the lack of materials with which to pack lunches. This thesis is borne out by data which show 
that attendance was lowest in area one, which had the lowest level of living. Some absence is also due to parental indifference, severe. winter weather, and isolation.

From 62 to 72 per cent of the students were over the "normal" age for their grade, while in the state as a whole 50 per cent are over-age. A relatively large proportion of students in area one also fail to pass on to the next grade each year. One-fourth of all students entering high school fail to graduate.

There are no secondary schools in the areas, but free transportation has been provided since 1933 for those desiring to attend the free public high schools in Webster Springs and Summersville. Free transportation to Richwood High School was inaugurated in 1939. An increasingly large proportion of eighth-grade graduates is taking advantage of this opportunity to secure a high-school education. The fact that Hacker Valley students must travel a greater distance than those in the other areas to reach high school is probably one of the explanations why the proportion of students attending from that area is smallest.

Vocational agriculture is offered in only one of the secondary schools in the two counties. Vocational home economics is offered in two of the three high schools. Although no data are available concerning the location and occupations of high-school graduates to serve as a guide in recommending changes in the curriculum, the introduction of vocational training of other types would undoubtedly fit future generations for better earning opportunities in vocations other than agriculture.

The boards of education in both counties were sponsoring WPA adult education projects and WPA and NYA National Defense training courses. A general lack of skilled workers on WPA had prevented either of the counties from teaching vocational subjects in the regular adult classes, but courses in automobile mechanics, woodworking and electricity were presented in the defense training schools. Not more than ten students from the two counties had been enrolled in the defense training courses in Webster Springs and Summersville at any one time.

The Webster County Board of Education also sponsored an NYA vocational training camp. In the summer of 1941, approximately 80 boys from all over the state were in residence, and 250 boys from Nicholas and Webster counties were attending day classes at Camp Caesar. The camp's program was composed of two parts: (1) a vocational training program consisting of courses in mathematics, cooking, typing, and woodworking; and (2) a national defense program consisting of courses in welding and sheet metal work.

Three-fourths of all farm and non-farm operators "plan" to continue living at their present locations indefinitely and to continue working at their present jobs as long as they are physically 
able. Many of those planning to move were searching for less isolated farms. Operators frequently mentioned other economic causes of dissatisfaction with present farms.

Only an occasional WPA worker claimed to be searching for another source of employment, probably because they knew there were few openings in the areas. Practically all other relief recipients intended to remain on relief as long as possible. A very few stated that they were planning to go outside of the counties in search of employment.

\section{OWNERSHIP AND TAXATION OF FOREST LANDS ${ }^{10}$}

The forest land of Nicholas and Webster counties is owned in small and large tracts, by farmers, commercial lumbermen, and others. It is the purpose here to analyze the ownership pattern of forest and farm lands, together with the prevailing tax policies, in an effort to determine the problems that are current, and the possibility of effecting long-time policies of utilization which will contribute to human welfare and to greater conservation of forest resources.

\section{FARM AND FOREST LAND TENURE}

Slightly more than one-third of the total land area of the two counties is owned by farmers (Table 11). In Nicholas County 15 per cent, and in Webster County 20 per cent of all land is in farm woodland. A significant feature of farm woodlands is that the average acreage per farm is only 27 acres in Nicholas and 42 acres in Webster County. From the standpoint of management and development this small acreage of woodland per farm is a serious deficiency. The large blocks of commercial forest lands, in the midst of which farm communities are located, are not operated in a manner which permits a management program that might be shared by farmers to any appreciable extent.

Owner and part-owner farmers control 82 and 66 per cent of the farm lands in Nicholas and Webster counties, respectively. Tenants operate 18 and 34 per cent in the respective counties. It is pertinent to recall that a large number of those farmers classified as tenants are a type of "squatter" on commercial forest lands. They have no definite boundary under their management. The only right which they possess is the privilege of a small patch of land to farm, and the permission to use dead wood for fuel. They have no access to woodland. From 22 large landowners it was learned that 13 allowed "squatters," either with or without contract. On the lands of the 13 owners, 807 "squatter-tenants" were residing. Usually these occupants pay no rent, but in cases where contracts are signed a nominal fee is charged, but seldom collected. For the privilege of building a "shack-shelter" and clearing a patch for corn they agree to fight fires and in other ways protect the property of the owner.

10 The data used in this section pertain to the entire area of the two counties, except as otherwise designated. 
The most unfortunate aspect of such settlement is the fact that "squatters" do not have access to land suited for agriculture from the standpoint of either location or quality of soil. Consequently, they live at a very low level, and rear large families in an environment which is not conducive to adequate education and training.

TAble 11-Ounership of Surface Lands in Nicholas and Webster Counties, West Virginia

\begin{tabular}{l|r|r|r|r}
\hline \multirow{2}{*}{ Owner } & \multicolumn{2}{c|}{ ACREAGE OF SURFACE } & \multicolumn{2}{c}{ PERCENTAGE OF TOTAL } \\
\cline { 2 - 5 } \cline { 5 - 6 } & Nicholos & Webster & Nicholas & Webster \\
\hline Farm-improved & 90.598 & 47,759 & 21.8 & 13.5 \\
$\quad$ forest & 61,401 & 71,545 & 14.7 & 20.2 \\
Commercial forest & 240,898 & 163,528 & 57.8 & 46.0 \\
State parks & 275 & $7,321^{2}$ & .1 & 2.1 \\
National forest & 23,434 & 64,707 & 5.6 & 18.2 \\
Total & 416,606 & 354,860 & 100.0 & 100.0 \\
\end{tabular}

1. The only state-owned lands in the two counties. In Webster County the land is leased to the state.

2 Owned by United States Department of Agriculture; leased to West Virginia Conservation Commission.

Commercial forest lands are held by several types of owners, including both public and private interests. Private owners include land-holding corporations, forest manufacturing corporations, coal companies, undivided estates, and individuals. The ownership map (Fig. 3) presents all private ownership in two categories: (1) corporate; and (2) individual or undivided estates. The lands of both types of owners have been "blocked" as much as possible to protect right-of-ways for the removal of coal and timber.

State-owned lands, other than school properties and road commission service garages, are confined to the Carnifax Ferry Battlefield State Park in Nicholas County. In Webster County the tract now known as Holly River State Park was purchased during 1938 and 1939 by the Farm Security Administration as a phase of its program of resettlement. Following purchase it was leased to the state for 99 years.

Federally owned and administered lands consist of that portion of the Monongahela National Forest which lies within the two counties. The map indicates the extent to which the Forest Service had acquired the area designated as the National Forest Purchase boundary. ${ }^{11}$ It is significant that the Forest Service is not insisting on total ownership within its purchase boundary. There are a number of private reservations, particularly in that portion of the Forest in Nicholas County, which are not the object of purchase because of their suitability for continued private use. Furthermore, it is of special interest that the Forest Service is making some pur-

11 To extend the boundary of a National Forest it is requisite under the provisions of the Weeks Act to establish a "purchase unit" adjacent to the existing boundary authorized by the National Forest Reservation Commission. After acquisition of a substantial acreage of land within the purchase unit, the boundary of the National Forest may be extended to include the area of this unit by Presidential Proclamation. State approval to Federal purchase of lands for the "conservation of forests" is given under authority of Chapter 1, Section 3, Code of West Virginia, 1937. 
ars

nts, nts. lart for rees :est the vho ded lem uch

on
Tir-
d a
res.
and
uce
on
I31,
ass-
the
ion
hat
rn-
cal
ent
per
est

ixiopthe nein l of -est

elfists an-ior lity 


\section{LAND OWNERSHIP}

NICHOLAS AND WEBSTER COUNTIES

WEST VIRGINLA

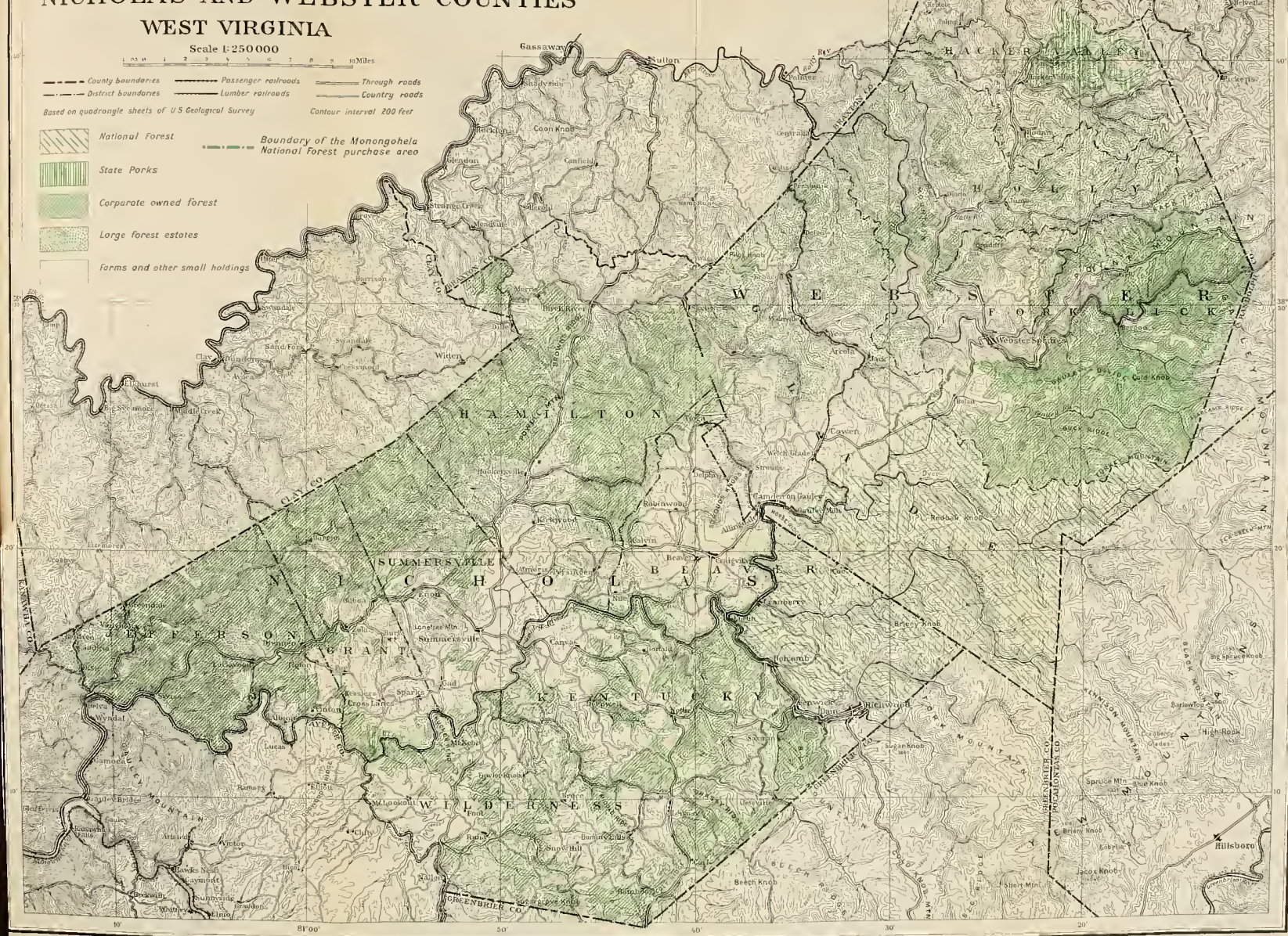


chases subject to life leases for aged owner-occupants. This appears to be a more feasible method of attaining man-land adjustments, than unqualified purchase and immediate-eviction of occupants. Furthermore, special occupancy and grazing permits are a part of the management program of these lands which are suitable for subsistence units and grazing purposes. Those special permittees occupying small units are given as much employment in the forest as possible, which adds to their total income. The attitude of the service in this regard is based on the facts that there are people who desire to live in the forest environment and that labor is needed in the management and care of the lands. However, the problem of supplying essential public services must be solved before such occupancy is generally permissible.

\section{TAX POLICY}

The history of taxation policy has had significant bearing on the present ownership and tax delinquency situation in West Virginia. Prior to 1933 both farm and non-farm real estate carried a large proportion of the tax load in the form of ad valorem taxes. In that year the State Assembly enacted the Tax Limitation and Property Classification Amendment which was designed to reduce permanently ad valorem taxes. Subsequently, the taxes paid on West Virginia farm lands dropped from 44 cents per acre in 1931, to 15 cents in 1933.12 The assessment was unchanged, $i$. e., assessment under both the old and new tax laws was supposed to be the current value. However, there are no impediments to a declaration that current assessments do not represent full sale value, or that additional revenue is essential to the proper functioning of government, and, hence, assessments may be increased. In fact, some local governments (county and municipal) have declared, during recent years, a flat raise in assessed values amounting to 10 or 15 per cent. This means that the future tax load which farm and forest lands will be expected to bear is uncertain.

The limitation law provides, in addition to a total rate, maximum rates that may be levied against the several classes of property for any specific purpose (Table 12). It will be noted that the total levy against farm property, including farm woodland, is onehalf that for commercial woodland. This feature is distinctive in that farms are assessed as a unit, and there is no direct method of ascertaining the relative tax load carried by the two types of forest property, except where woodland is separately located.

The current assessment on farm lands is very low. Small selfsufficing units are not expected to carry a large portion of the costs of government. In addition, they take the Class II rate, which cannot be above $\$ 1$ per $\$ 100$ valuation, unless the debt contracted prior to 1932 necessitates an excess levy. ${ }^{13}$ Because of the impossibility 
of separating farm and forest land that has been assessed as a unit and of the fact that a small proportion of the woodland is in farms, we shall turn our attention to taxation policies regarding commercial forest lands.

TABLE 12-Maximum Rates of Tax Levy Authorized by Tax Limitation Amendment, West Virginia, $1933^{1}$

\begin{tabular}{|c|c|c|c|c|}
\hline \multirow{2}{*}{ PURPOSE } & \multicolumn{4}{|c|}{ RATES PER $\$ 100$ BY CLASSES OF PROPERTY ${ }^{2}$} \\
\hline & 1 & 11 & III & IV \\
\hline & cents & cents & cents & cents \\
\hline 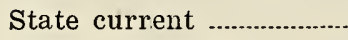 & .25 & .5 & 1.0 & 1.0 \\
\hline County current & 9.40 & 18.8 & 37.6 & 37.6 \\
\hline County debt & .75 & 1.5 & 3.0 & 3.0 \\
\hline District debt & 4.15 & 8.3 & 16.6 & 16.6 \\
\hline School current .................. & 19.60 & 39.2 & 78.4 & 78.4 \\
\hline 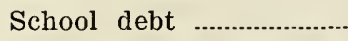 & 1.85 & 3.7 & 7.4 & 7.4 \\
\hline School improvements & 1.50 & 3.0 & 6.0 & 6.0 \\
\hline Municipal current .......... & 9.50 & 19.0 & -..-... & 38.0 \\
\hline Municipal debt & 3.00 & 6.0 & ........ & 12.0 \\
\hline Total & 50.00 & 100.0 & 150.0 & 200.0 \\
\hline
\end{tabular}

1 Chapter 67, Section 6, Acts of the Second Extraordinary Session of the 1933 Legislature of West Virginia.

2 Class 1-Personol property.

II-Form real estate, including farm woodland, and other property occupied by the owner or bona fide tenant.

III-Forest lands and other rural commercial properties.

IV-Commercial properties located within municipalities.

Assessment of real estate in West Virginia is divided according to the extent of ownership. For instance, the assessment of any area may be in fee, or the rights may be assessed separately as surface, coal, oil, gas, and timber. Obviously, assessed values will vary, depending on the quality of the resources, and whether the assessment is revised when a change in quality occurs. The latter, however, is not always done. There is reason to believe that a more potent factor in determining assessed values is the pressure that is brought to bear on local officials for a change in tax base. ${ }^{14}$

Assessed values per acre of Class III lands are shown in Table 13 by districts of Nicholas and Webster counties. A large part of the variation between districts may be due to quality of resources, including inaccessibility. There is a wide range in fee assessments $(\$ 2.00$ to $\$ 20.00$ per acre), as well as in surface valuations.

14 The county court is outhorized as a Board of Equalization and Classification to review assessments and recommend revaluation and reclassification when found desirable. 
TABLE 13-Assessments According to Types of Land. Nicholas and Webster Counties, West Virginia, 1941

\begin{tabular}{|c|c|c|c|c|c|}
\hline \multirow{2}{*}{$\begin{array}{c}\text { County and } \\
\text { district }\end{array}$} & \multicolumn{5}{|c|}{ VALUE PER ACRE-BY TYPES OF PROPERTY 1} \\
\hline & Fee & Surface & Coal & Oil E Gas & Timber \\
\hline Nicholas: & dollars & dollars & cloilars & clollars & dollars \\
\hline Beaver & 11.99 & 7.73 & 5.67 & 1.00 & ........ \\
\hline Grant & 14.40 & 8.00 & 5.99 & 1.00 & ....... \\
\hline Hamilton & 13.87 & 5.77 & 6.62 & 1.00 & ......... \\
\hline Jefferson & 14.34 & & 6.35 & 2.00 & ........ \\
\hline Kentucky & 13.68 & 6.39 & 10.47 & 1.00 & 5.00 \\
\hline Summersville & 14.21 & ...... & 5.68 & 1.00 & 25.00 \\
\hline Wilderness & 10.94 & 14.69 & 6.35 & 1.00 & -....... \\
\hline \multicolumn{6}{|l|}{ Webster: } \\
\hline Fork Lick & 16.62 & 10.16 & 7.71 & 0.75 & 17.76 \\
\hline Glade & 10.98 & 5.30 & 5.85 & .75 & .......... \\
\hline Hacker Valley & 8.04 & 5.97 & 5.91 & .75 & 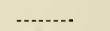 \\
\hline Holly & 9.72 & 4.41 & 6.72 & .75 & 13.00 \\
\hline
\end{tabular}

1 From an analysis of all Class III forest property on land books; does not include farm lands or municipal lands.

The amount of taxes levied per acre of forest land is the result of three variables: (1) assessments; (2) district debt; and (3) the extent of ownership (fee or surface). The extent of ownership should have nothing to do with the taxes paid from forest revenues. In reality, owners of fee properties including undeveloped minerals endeavor to meet the total tax load by exploiting the forest.

Data in Table 14 indicate that the taxes levied per acre of commercial forest land in 1941 varied from 8 to 30 cents. This wide range exists in connection with surface lands alone. In contrast to the taxes paid per acre of commercial forest land (Class III), forest lands owned by farmers, but assessed separately, are subject to a tax levy of 5 to 9 cents per acre, for surface and fee ownership, respectively (Table 15). It is apparent that commercial forest land owned by farmers has an appreciable advantage under the present tax policy. The advantage arises largely as a result of difference in rates applied to the two classifications inasmuch as the assessments are not greatly different.

TABLE 14--Taxes Levied per Acre According to Size of Forest-land Holdings, Nicholas and Webster Counties, West Virginia, 1941

\begin{tabular}{|c|c|c|c|c|}
\hline \multirow{2}{*}{ County } & \multirow{2}{*}{$\begin{array}{l}\text { Extent of } \\
\text { ownership }\end{array}$} & \multicolumn{3}{|c|}{ TA.XES LEVIED PER ACRE BY SIZE OF HOLDINGI } \\
\hline & & Under $500 \mathrm{~A} . \quad !$ & $501-1500 \mathrm{~A}$. & 1501 A. and aver \\
\hline & & cents & cents & cents \\
\hline Nicholas $^{2}$ & $\begin{array}{l}\text { Fee } \\
\text { Surface }\end{array}$ & $\begin{array}{l}27 \\
16\end{array}$ & $\begin{array}{r}25 \\
S\end{array}$ & $\begin{array}{l}2 S \\
30\end{array}$ \\
\hline Webster? & $\begin{array}{l}\text { Fee } \\
\text { Surface }\end{array}$ & $\begin{array}{r}19 \\
9\end{array}$ & $\begin{array}{l}21 \\
10\end{array}$ & $\begin{array}{l}23 \\
16\end{array}$ \\
\hline
\end{tabular}

1 Class 111 woodland only.

2 Calculations based on 1941 levy for Kentucky district, which has the highest district debt in Nicholas County.

3 Same rate of levy is applicable over entire county; no district debt.

NOTE: The average taxes levied per owner-operated farm in 1939 were $\$ 13.00$ and $\$ 7.00$ in Nicholas and Webster Counties, respectively. (See U. S. Census af Agriculture, 1940.) 
This advantage has important implications in connection with the costs of holding timber for future cuttings. Likewise, the comparatively high tax rate on commercial lands may discourage owners from operating under a long range management program, and may encourage exploitation. However, it is the consensus of most operators that the present tax load of Class III lands is not excessive. At the same time, they do not expect to hold land over long periods for reforestation.

It may be appropriate to point out some irregularities which are allowed in the assessment and levy procedures. (1) Farmers owning large acreages of forest land (commercial) are allowed the lower levy rate (Class II). (2) Considerable variation apparently is permitted in assessments, although the variation in the quality of the resource may not justify the difference. It is shown in a subsequent section that many assessments are the result of bargaining with the local assessor and the Board of Review and Reclassification. (3) Local officials in Webster County have circumvented the intention of the maximum rate by assessing for district debt when none exists in order to increase local revenue.

TABLE 15-Assessment and Taxes Levied on Class II Forest Lands, Webster County, $1941^{1}$

\begin{tabular}{l|c|c|c}
\hline $\begin{array}{c}\text { Extent of } \\
\text { ownership }\end{array}$ & Acreage & $\begin{array}{c}\text { Assessment } \\
\text { per acre }\end{array}$ & $\begin{array}{r}\text { Taxes levied } \\
\text { per acre }\end{array}$ \\
\hline Fee & 3,077 & $\$ 10.51$ & $\$ 0.09$ \\
Surface & 18,950 & 6.02 & .05 \\
\hline
\end{tabular}

1 Based on Class 11 properties located and assessed independent of the remainder of the farm property.

\section{Revenues and Expenditures}

Local public services, excepting roads, schools 15 and state policing, are supported largely from the general property tax, which is administered by the county. The transfer of all roads to the State in 1932 released real property from a heavy tax burden, particularly in the less productive counties. The district road bonds contracted prior to 1932 were not transferred, and the counties still assess for amortizing these bonds. They represent the only bonded indebtedness of the rural districts of the two counties. A tax rate in excess of the maximum established by the Limitation Amendment is required to amortize this debt.

Since both primary and secondary roads are now financed entirely from the gasoline tax and WPA funds and since other state services are not based on the general property tax, an in-. significant amount of revenue is collected by the counties for state purposes. ( $\$ 815$ in Nicholas County and $\$ 594$ in Webster County in 1941.) Slightly more than 50 per cent of all property taxes represent current costs of public schools. In addition to the compara-

15 In addition to state aids, the general property tax provides about one-fourth the cost of primary and secondary education. 
tively small amount of school funds from this source, these counties share in state aid funds, which are derived largely from a retail sales tax. The remaining 50 per cent of the total levy is for county purposes. In Nicholas County, this levy is divided about equally between current operating expenses and contractual debt. The cost of debt in Webster is comparatively low since the total bonded indebtedness of this county is only $\$ 40,000$. There are no outstanding district road bonds, while in Nicholas County four magisterial districts are obligated to levy for secondary road bonds contracted prior to 1932.

Commercial woodlands constitute approximately 30 per cent of the tax basis in the two counties and are subject to about 35 per cent of the taxes levied (Table 16). It is obvious that future utilization, productivity, and ownership of forest lands is a very important factor in the local economy, from the standpoint of both private and public income. In fact, commercial forest lands produce almost three times the volume of local taxes collected from farm real estate. This means that local government is dependent on continuous revenue from either lumbering or mining operations on Class III lands. Unless mining quickly takes the place of an almost vanished lumbering economy, large areas of forest lands may again become delinquent, even with a lighter tax load than existed prior to 1932. The reduction in both rates and assessed values, and the expectancy of coal development encouraged many delinquent owners to redeem their lands, but they probably will not hold them indefinitely unless income is forthcoming. The current increase in the demand for coal as a result of war-time production is encouraging expansion in mining. The continuation of this development is dependent on future demands for coal, particularly since much of the coal underlying this area is considered submarginal when prices are low.

TABLE 16-Assessed Valuation and Taxes Levied by Types of Property.

Nicholas and Webster Counties. West Virginia, 1941

\begin{tabular}{|c|c|c|c|c|c|c|}
\hline \multirow{2}{*}{$\begin{array}{l}\text { Property } \\
\text { Class }\end{array}$} & \multicolumn{3}{|c|}{ NICHOLAS } & \multicolumn{3}{|c|}{ WEBSTER } \\
\hline & Value & Taxes & Percentage & Value & Taxes & | Percentage \\
\hline & $(000)$ & Dollars & Per cent & $(000)$ & Dollars & Percent \\
\hline I & $\$ 1,459$ & 7,359 & 4.3 & $\$ 1,008$ & 4,301 & 3.4 \\
\hline II & 2,778 & 25,919 & 15.0 & 1,367 & 11,673 & 9.2 \\
\hline III & 6,499 & 105,408 & 61.0 & 5,599 & 95,624 & 75.2 \\
\hline$(\mathrm{III}-\mathrm{F})^{1}$ & $(3,566)$ & $(57,879)$ & $(33.5)$ & $(2,750)$ & $(46,976)$ & $(37.0)$ \\
\hline IV & 1,943 & 34,161 & 19.7 & 909 & 15,533 & 12.2 \\
\hline Total & $\$ 12,679$ & 172,847 & 100.0 & $\$ 8,883$ & 127,131 & 100.0 \\
\hline
\end{tabular}

1 The property class $111-\mathrm{F}$ is improvised here to differentiate between all Class 111 property and commercial forest lands $(I I I-F)$.

\section{Tax Delinquency and Reversion}

Although present levy rates are slightly higher than they were in 1933, they still represent a drastic reduction compared to those of 1931 and prior years. In spite of this encouragement to tax pay- 
ment, large areas of cut-over lands were not redeemed immediately. Until late in the 1930's and the boom of interest in subsurface (coal) development, there appeared to be definite lack of interest in holding cut-over lands at any cost. During the period 1935 to 1940 large tracts not of great value for coal became delinquent.

At the present time the tax load of the small farms is not a problem. The taxes paid on the farm of average size (70 acres@ $.15)$ is less than twelve dollars on the basis of an assessment of $\$ 10$ per acre. Many of the small self-sufficing farms are subject to an annual tax levy of less than seven dollars. While it is true that an appreciable number of small farms are delinquent, the cause hardly can be termed excessive taxation. Lack of income in excess of the demands for family living, and negligence, are more likely causes.

In the two counties more than 77,000 acres of commercial woodland were tax delinquent in 1941 (Table 17). This represents about one-fifth of the commercial woodland in privately owned tracts of 500 acres or more. More than half of this delinquent acreage is represented by tracts with an average size of more than 5,000 acres. Eighty-seven per cent of the current delinquency of commercial forest lands has occurred since 1936.

TABLE 17-Tax Delinquency of Forest Lands According to Size of Holding, Nicholas and Webster Counties, 1941

\begin{tabular}{|c|c|c|c|c|c|c|}
\hline \multirow[b]{2}{*}{$\begin{array}{c}\text { Acreage in } \\
\text { holding }^{1}\end{array}$} & \multicolumn{3}{|c|}{ NICHOLAS } & \multicolumn{3}{|c|}{ WEBSTER } \\
\hline & $\begin{array}{c}\text { No. } \\
\text { tracts }\end{array}$ & $\begin{array}{c}\text { Total } \\
\text { acreage }\end{array}$ & $\begin{array}{c}\text { Acreage } \\
\text { delinquent }\end{array}$ & $\begin{array}{c}\text { No. } \\
\text { tracts }\end{array}$ & $\begin{array}{c}\text { Total } \\
\text { acreage }\end{array}$ & $\begin{array}{c}\text { Acreage } \\
\text { delinquent }\end{array}$ \\
\hline Under 1,000 & 26 & 18,954 & 6,927 & 17 & 11,676 & 4,279 \\
\hline $1,001-3,000$ & 25 & 39,997 & 3,758 & 22 & 33,368 & 11,094 \\
\hline $3,001-5,000$ & 8 & 30,660 & 4,447 & 5 & 18,538 & 7,242 \\
\hline 5,001 - over & 13 & 152,732 & 22,794 & 8 & 68,241 & 16,610 \\
\hline Total & 72 & 242,343 & 37,926 & 52 & 131,823 & 39,225 \\
\hline
\end{tabular}

1 Includes only tracts of 500 acres or more.

In all probability these cut-over lands will become a greater problem as the general tax load becomes heavier, particularly where subsurface development does not warrant a continuation of private ownership. Practically all owners have indicated that they will not continue to pay taxes unless some immediate income is forthcoming. Mining is the only expectation in most cases.

In order to understand more completely both private and public policy regarding the status of forest ownership and operation, it will be well to review briefly the policy of the past decade. Until very recently state and local governments have held a negative attitude toward lands reverting through the process of tax delinquency. In fact, prior to 1940 , there was no provision for either the state or local governments to possess and manage chronically delinquent lands. Consequently, the reversion of land to the state had never been complete, and there had been no limitation on the period of delinquency, following which redemption was not possible. Re- 
gardless of preceding circumstances, much encouragement has been given to return delinquent lands to a current tax status. In other words, rather than severely penalizing delinquency, past levies have often been partially sacrificed in order to place lands on the current land books. A little revenue has been considered more desirable than none.

Following the widespread delinquency of the early 1930's and the reduction in ad valorem levies resulting from the classification and limitation amendment, the local governments took further steps to replace delinquent lands on their current tax lists. These steps were largely extra-legal, but approved by the State Auditor. Provision was made for the revaluation of delinquent lands "for redemption purposes only." In addition, interest and other penalties, or fees, were cancelled. The fact that only 20 per cent of the commercial woodland is now delinquent may be attributed largely to this lenient policy. An important corollary has been that some owners may have permitted delinquency in anticipation of obtaining revaluations for redemption purposes along with the cancellation of all penalties.

A review of the approvals for revaluation on file in the State Auditor's Office indicates that this action has been exceedingly important in past state and local land policy (Table 18). During the period 1933 to 1939 more than 111,000 acres of commercial forest lands in the two counties were revalued for redemption purposes. Most of this acreage represented holdings of one thousand acres or more. Assessments per acre at the time of delinquency varied from $\$ 9.00$ to $\$ 16.00$. By revaluation, without legal provision, these assessments were reduced 57 to 83 per cent for redemption purposes. The lower assessment was the basis for payment of back taxes for all years delinquent. Thus, more than 35,000 acres of delinquent lands in Webster County assessed at approximately $\$ 12.00$ per acre were revalued at $\$ 2.00$ per acre. Reductions of this magnitude have been responsible for the elimination of what otherwise might have been a serious delinquency condition at present.

Following redemption on the basis of revaluation, lands were reentered on the land books at the original assessment or a revised value independent of the one used for redemption. In most instances, however, the current assessed values of those properties revalued for redemption are 6 to 36 per cent lower than they were when delinquency occurred.

Before 1939, the process of revaluation for the redemption of tax delinquent lands described above consisted of an agreement between the landowner, or his representative, and the local assessor that a revaluation was reasonable. Subsequently, the assessor submitted the revalue to the State Auditor for approval, and if approved, the State Auditor received payment and reported the property current. Successive reductions within the course of a single year were often made in an effort to obtain a current status for some large tracts. 
TABLE 18-Revaluation ${ }^{1}$ of Forest Lands for Redemption of Delinquent Taxes, Nicholas and Webster Counties. 1933-39

\begin{tabular}{l|l|l|l}
\hline \multirow{2}{*}{ I TEM } & \multicolumn{3}{|c}{ ASSESSMENT BY SIZE OF HOLDING ${ }^{2}$} \\
\cline { 2 - 3 } & Under 300 A. & $301-1,000 \mathrm{~A}$. & $\begin{array}{l}1,001 \mathrm{~A} . \\
\text { and over }\end{array}$ \\
\hline
\end{tabular}

Nicholas County:

Total acres

Assess, at delinquency (per A.)

Revaluation (per A.)

Per cent reduction

$\$ 12.00$

4.63

61.00

Current assessment (per A.)

11.07

Per cent reduction

8.00

8,203

$\$ 15.10$

4.87

68.00

12.76

15.00

47,279

$\$ 16.31$

6.93

57.00

15.37

6.00

Webster County:

Total acres

7,358

$\$ 10.72$

2.30

79.00

8.74

18.00
9,477

$\$ 8.94$

1.89

79.00

7.01

22.00
35,656

$\$ 12.47$

2.09

83.00

8.04

36.00

1 Revaluation for redemption purposes only.

2 Includes a few surface holdings but consists mainly of fee assessments-Class III property only.

Requests for revaluation became so frequent that by 1939 the State Auditor asked the Legislature to authorize some provision for handling future requests. Subsequently, reclassification and revaluation for redemption purposes only were legalized, ${ }^{16}$ to be effective March 6, 1941. The original procedure was merely approved by statute, except that the act provided for approval of the reclassification and revaluation by the county court before the application is submitted to the State Auditor. This act is so recent that only a few cases have gone through the revised procedure. A review of those cases approved by the court shows that they have recommended 80 per cent reductions in assessed values as the basis for computing all delinquent taxes. These are almost as drastic as the most extreme cases approved under the old procedure.

A more important provision of Chapter 11-A is the time limitation on the redemption of delinquent lands through this process ${ }^{17}$ and the clarification of the procedure by which lands finally become state property. To bring order to the procedure for the disposal of delinquent lands and to eliminate the disorder accumulated during the preceding years, it was decreed that all delinquency, including interest and charges, prior to 1929 was "declared to be fully paid"18 (canceled). Ail interest and other penalties, by the same act, were canceled for delinquency up to and including the year 1932 . Reclassification and revaluation were authorized covering all delinquency subsequent to 1929 and subject to redemption; but the act clearly states that such revaluations must be reviewed by the Board of Review and Equalization (County Court), and that the revalua-

16 Chapter II-A, Article 3, Section II, Code of West Virginia, 1940.

17 Assuming that additional tax moratoriums are not declared by the legislature, which may nullify the intentions of the 1940 Act.

is Chapter 11-A, Article 4, Section 54, Code of West Virginia, 1940. 
tion must be consistent with the prevailing assessments on other properties for the same years. This is the stipulation which apparently has been ignored in making the 80 per cent reductions, under the new law. All delinquency subsequent to 1932 was subject to all interest, fees and penalties provided in the act, but the possibility of revaluation for redemption purposes was continued.

Forfeited lands may not be recovered after January 1942, except as provided in the new act. ${ }^{19}$ Under the provisions of the act taxes become delinquent on November 1 of each levy year and all delinquent properties are to be sold at tax sale in December following. All lands not redeemed before sale, or purchased at the sale, will be sold to the state for the charges against them. The former owner is allowed to redeem his lands through the medium of the Commissioner of forfeited and delinquent lands (State Auditor) at any time during the 18 months following sale to the state. During January following the expiration of this period the State Commissioner certifies to the County Court that lands not redeemed again will be offered for sale and the Circuit Court is instructed to fix a date for holding sale prior to March 1 following. ${ }^{20}$ At this time all properties yet unredeemed are offered for sale and if again not purchased by private interests they are automatically sold to the Public Land Corporation of West Virginia for the charges against them. Following this sale the former owner may still have a chance to redeem his lands through the Deputy Land Commissioner of his county. ${ }^{21}$ However, as soon as titles have been certified and the sales, either to private purchasers or the Public Land Corporation, have been confirmed by the Auditor, the right of redempis terminated.

\section{Public Land Corporation}

This legislation is indicative of a shift toward a more positive policy of state ownership of lands which are more or less ill suited for private ownership under the prevailing tax load. The Public Land Corporation ${ }^{22}$ is vested with the title of the state for such lands as are acquired by it. It has the authority to "designate lands to which it has title for development and administration for the public use including forestation, stock grazing, agricultural rehabilitation and homesteading ... It shall convey, assign, or allot lands to the title or custody of proper departments or other agencies

19 Chapter 11-A, Articles 3 and 4, Code of West Virginia, 1940.

20 This section was declared uncónstitutional. Edgar B. Sims, Auditor, et al. V. Jake Fisher, Judge, 1943, No. 9466. The court ruled that the Act fails to provide for a judicial ascertainment before any order of sale, that the lands proceeded against are, in fact, subject to sole, and that it attempts to impose administrative powers upon the Circuit Courts. This decision apparently involidotes the statute providing that unsold tax delinquent lands be purchased by the Public Land Corporation, at least to the extent that no substitute step has been provided for thot portion of the acquisition procedure which was declared unconstitutional.

21. The Deputy Land Commissioner is the duly authorized agent of the Public Land Corporation.

22 The Public Land Corporation was authorized by Art. 2-A, Chap. 37, of the West Virginia Code (1933) to consist of the Governor (ch.). Auditor, Com. of Agri., Att. General, and the Dir. of the Engineering Exp. Sta., West Virginia University. However, until the enactment of Chap. 11-A (1940), there was no procedure by which the Corporation could ocquire forfeited lands, i. e., there was no termination of the redemption period. 
of state government for administration and control ... The corporation shall make proper lands available for the purpose of cooperating with the government of the United States in the relief of unemployment and hardship." ${ }_{23}$ "For the purpose of consolidating lands under either state or Federal administration, the corporation may sell, purchase, or exchange lands or stumpage."24

The fact that the state is ready to correct the loose and negative land policies of the past is implicit in the legislation. Consequently, the State Land Corporation has been given the power to guide the utilization of lands for the welfare of all. Not only does it have the authority to determine the best use for lands reverting to the state through tax delinquency, but it may "Acquire from individuals ... by purchase, lease or agreement any lands that may be necessary for the public use." 25 This could be interpreted to mean that the Corporation might purchase, lease, or make an agreement for the purpose of controlling the use of any lands in the interest of the public good.

The policy of the Corporation, however, is not prescribed with regard to what type of lands will be retained by the state, and what reservations might be required of lands that are possessed and later sold to private interests. This would be desirable from the standpoint of assuring the public that certain types of land would be retained for public development in the interests of social welfare. Furthermore, full assurance should be had that lands which are developed at public expense would not be sold later to private interests for exploitation of the values achieved at public expense. For example, it might be well for legislation of this type to set forth the conditions and provisions under which land would be sold to private interests following rehabilitation. As assurance against repeated exploitation and reversions to the state the deeds covering the transfer of forest property to individuals might carry the stipulation that certain desirable management and cutting practices are to be followed. Such reservations by the state could be enforced effectively on any sizable boundary of forest land.

The proper functioning of the Public Land Corporation will require the services of a qualified full-time administrator with the necessary technical assistants for aiding the work in the counties. The Agricultural Experiment Station, the State Conservation Commission and the State Planning Board, should be designated to assist in studying the character of lands acquired through tax reversion and to determine the most desirable use, and the care that should be provided. In this process there should be a determination as to whether specific lands should be retained by the state or sold to private interests. ${ }^{26}$

23 Chapter 37, Article 2-A, Section 8, Code of West Virginia (1933).

24 Ibid., Section 5.

25 Ibid., Section 3.

${ }_{28}$ The 1943 Legislature considered a proposed Art. 5 to Chap. 11-A of the 1940 law, which would have made provisions along this line. 
Legislation of this type should be adequately flexible in order to facilitate handling unpredictable circumstances by the Corporation. On the other hand it would be well for legislation to provide certain desirable objectives and guides for its activities. For example, desirable adjustments between people and land could be achieved by retaining all reverted lands of a certain character and location. Future settlement could be guided, and public costs might be reduced by gradually relieving submarginal, remote areas of scattered settlement. It is quite possible that this and similar types of adjustments might be overlooked unless the statutes prescribe in more detail the policies that should be followed.

In any event, the function of policy determination should not be left to the 55 county governments. Public interest will not be adequately served by local agents.operating independent of a unifying policy for handling certain types of land. In order for a state to administer public lands satisfactorily, the procedures must be above the prejudices and selfish interests of local governments. In Nicholas and Webster counties, for example, the people will be reluctant to see more of their land removed from the tax rolls, although the amount of tax income to be received in the future may be negligible.

\section{FOREST PRODUCTION AND POLICIES}

It has been shown that farmers own only a small portion of the forest lands of Nicholas and Webster counties. Most of the forested area is still owned by operating and non-operating commercial interests. Furthermore, public ownership is being expanded rapidly as timber resources are depleted and private interests no longer find it feasible to retain ownership of the surface. The practices and policies of the prevailing forest industry determine to a large extent what is possible in the future and in turn, the interest and action that the public may have to take for insuring public welfare in both the present and the future.

\section{Lumber Manufacturing ${ }^{27}$}

On January 1, 1942, there were three two-band mills operating in the two counties. All three companies had been operating for several decades-one since 1870. Three single-band mills of more recent origin were producing appreciable volumes of lumber. Approximately 20 portable, circular mills operate as scavengers on the small boundaries and low quality timber left by the larger operators. A number of these smaller mills have recently begun operation again in response to a greater demand for low-quality lumber and mine supplies, after having been idle for several years.

Lumber production in 1941 was nearly double that of 1938 . The four large band mills manufactured $47,575,000$ board feet in

27 All operating policies and cost dota pertain to the time when information was obtainedfall of 1941 . 
1938 , compared to a production of $83,630,000$ in 1941 . These mills operate the year round, and obtain the bulk of their timber from large boundaries which they own as "timber only" or in fee simple.

Portable mills usually are operated by part-time farmers, former woodsmen, and mechanically inclined men recognizing no alternative opportunities. With two or three exceptions they operate as custom sawyers, manufacturing low-quality lumber for local consumption. These mills are powered by small steam boilers, or by improvised gasoline units, and are capable of handling only light logs. Data obtained for the 18 portable mills operating on November 1, 1941, indicated that they would cut approximately 4,796,000 board feet in 1941 as compared to 3,470,000 in 1938 .

An important feature of the trend in production for both stationary and portable mills is not evident in the above volume figures. Until recent years forest manufacturing in this area consisted of sawing rough lumber. Export trade took choice lumber of large dimensions. Finishing plants in other locations processed rough lumber for domestic building purposes. Two major shifts have taken place during the past 15 years. (1) The large stationary mills are adding much value to their product by processing dimension supplies and finished building materials of all descriptions. (2) Both stationary and portable mills are salvaging large quantities of wood as by-products, such as lath, mine wedges and headers. By so doing, much low-quality wood which would otherwise be left in the woods is utilized to advantage, and less waste is permitted. These firms are endeavoring to prolong their operations by adding greater value to their product, inasmuch as it is not possible to move to virgin timber.

Recent expansion in coal development has stimulated the cutting of large acreages for mine supplies. Growing timber, down to four inches in diameter, is acceptable for mine props, wedges, headers, and the like. Many small and large tracts alike have been cleared of all merchantable mine timber. Some contractors and several of the small portable mills specialize in mine supplies.

Policies: Portable mills lack the equipment necessary to permit operation during severe winter weather. Logging may be done by the mill operator or may be contracted to special crews. From 10 to 25 per cent of the skidding for stationary mills is done by the "overhead" method, and a large portion of the remainder by tractor. Both overhead and tractor skidding are excessively destructive to growing timber. On the other hand, the rugged topography of some lands, almost necessitates the overhead method if the timber is to be removed. Tractor skidding, too, is an attempt to speed up the logging process and provide greater economy in operation.

'Timber sale contracts usually carry a stipulation to the effect that nothing is to be cut under $14^{\prime \prime} \mathrm{d}$. b. h., except when needed for skidding fenders and other development purposes. It is generally conceded that this privilege has been abused in recent years. The 
demand for small timber is good, and with a lack of more profitable alternatives, extremely small timber is processed under the disguise of being necessary for development purposes.

The size of timber now being removed is indicated by a size classification of $492 \operatorname{logs}$ at one assembly point. More than 69 per cent of the logs were under 18 inches in diameter. Only 9 per cent were 27 inches and larger. Approximately 8 per cent, more than half of which were butt logs, were less than nine inches in diameter.

Prices paid for stumpage and logs vary widely, partially owing to the species, quality, and accessibility of location. The latter is highly important for large areas of forest land. Stationary mills paid from $\$ 3.00$ to $\$ 10.00$ per M. for stumpage, while portable mills paid $\$ 2.50$ to $\$ 4.00$ per M. The low prices paid by the latter undoubtedly indicate lower quality timber, together with purchases of timber on very small boundaries from owners who are not aware of timber values.

Although the evidence is not conclusive, there is some reason to believe that if owners of good timber were being paid a stumpage price more in line with the value of such timber to the mills they would have greater incentive to conserve and maintain timberproducing lands than under prevailing prices.

\section{Pulp and Paper Production}

In 1922 a sulphite (softwood) pulp mill was established in Nicholas County. It operated more or less successfully until changing hands in 1938. After this date the new owners utilized no local pulpwood, but imported pulp from another mill outside the state. The entire plant was transferred during 1941 to a location accessible to southern pulpwood.

During 1941 two dealers in the two counties handled a total of 7,900 cords of pulpwood, approximately 46 per cent of which was hardwood. Two plants located outside the state consumed this supply of pulpwood since there are no local manufacturers. More than 87 per cent of the total pulpwood sold in the counties in 1941 was taken from commercial forest lands by a single company. This means that farmers and small owners either do not have a supply of timber or do not find it profitable to cut it.

The prices paid to farmers and small owners for the small quantity purchased were $\$ 8.00$ per long cord (160 cu. ft.) for softwood and $\$ 7.75$ for hardwood f.o.b. the railroad. Since the only railroad available to private shipping is from 30 to 80 miles removed from the supply, small owners reported that after paying hauling costs to the railroad only $\$ 3.50$ to $\$ 4.00$ was left as compensation for stumpage and labor in preparing the wood. It was the consensus that present prices were too low, and that owneroperators should have $\$ 5.00$ to $\$ 6.00$ for stumpage and labor in order to supply pulpwood at a level above a subsistence wage. 
The commercial operator who is cutting most of the present supply from this area is able to compete at greater advantage under present prices than farmers. The wood is taken from lands being cut for lumber, while roads and rail transportation into the forests are there for the purpose of logging the larger timber. Under these circumstances pulpwood production simply means closer cutting than would otherwise be done. Since the investments in transportation facilities are made for another purpose, and since no attention is given to a long-time management program on land already possessed, anything that can be gleaned from the land in excess of variable costs is an offset against fixed costs of the major lumbering operation. This is another way of extending the margin of lumber operations in order to realize the greatest immediate profits.

\section{Charcoal}

A recent innovation in West Virginia forest utilization is the construction and operation of approximately 30 charcoal ovens in the southwestern portion of Nicholas County. The demand for charcoal to be consumed in the manufacture of high-carbon steel and various chemicals in the nearby Kanawha Valley industrial area stimulated the introduction of this enterprise.

During the first two years of operation, the ovens completed were supplied with slabs from nearby saw mills, for which the buyers paid $\$ 3.00$ per cord, delivered at the ovens. In this way, the waste from the mills was turned into a by-product, another instance of closer utilization. In expanding this enterprise it has become necessary to supplement slabs with cordwood.

These charcoal ovens take from 56 to 87 cords each of wood every 24 days. The operators have based their investment on the expectation that the large areas of small second growth timber in proximity to the plants will furnish wood for charcoal manufacture. They have acquired a tract of approximately 5,500 acres of this type of timber to supplement and eventually replace the current supply of slabs.

This operation does not anticipate a long-time management program; in fact, the surface has not been acquired. The policy of selling only the timber, with a specified period for removal, forces the operator to exploit the resources as rapidly and completely as possible. Not only small growing trees down to two or three inches are taken, but all hollow and other cull trees which have heretofore functioned as seed trees in cut-over areas, are potential charcoal wood. Uncontrolled expansion of this type of cutting may reduce the forest resources of the area to the extent that the land will be practically worthless for several generations.

\section{Other Forest Industries}

One wood-products mill is in operation at Richwood, Nicholas County. Clothes pins, wood dishes, and novelties are produced in substantial volume. More than 200 persons are given regular em- 
ployment, about half of whom are women. Outside of the town where the employees live, this mill does not influence the economy to any significant extent. No wood is purchased from owners of small tracts. It is supplied by a single lumber company from its large holdings.

In years long past, large quantities of tanning bark were sold from this area. A large tannery, now gone, was located near Richwood. Exhaustion of certain types of timber was responsible for the passing of this enterprise locally. There are, however, several large tanneries in neighboring eastern counties which continue to operate.

Another interesting enterprise which utilizes the Chestnut, killed by blight, is a small post and fence mill in Webster County. Although this enterprise is of very limited scope, it is indicative of the attempt to utilize available resources as a source of earnings. The product is marketed to wholesale fence dealers in the larger cities, and is intended for "show" fencing on country estates. Whether such an enterprise can be based on other more expensive types of timber after the chestnut is decayed beyond use depends entirely on demand. In any instance, the demand for this type of fencing material is very limited and probably would not bear extensive development.

In general, competition from other areas, and the tendency to divert attention from a future dependent on forest production and manufacturing, to the development of coal have not encouraged wood processing industries. The future of wood-processing developments for utilizing the hardwoods of the Appalachians is uncertain. Such products as pins and dishes require a relatively small volume of timber, compared with the potential production of this region. On the other hand, rough lumber production requires only a small number of people and large areas of merchantable timber, which have been almost exhausted. Perhaps the future of forestry is dependent on a type of forest management that will anticipate a reasonable volume of continuous production and closer utilization. Closer utilization may consist of intensifying present tendencies toward finished materials, and an expansion of new types of wood industry.

\section{Forests in Relation to Coal Mining}

Until recent years, the cost of mining and lack of transportation facilities have rendered mining in this area submarginal to the coal fields in the southern part of the state. Most of the large corporate land holdings have been acquired or retained by coal interests in fee. In recent years there has been a tendency, as timber is cut, to sell the surface and reserve all mineral rights. In addition, some of the companies have consolidated large areas of coal land by the purchase of mineral rights under farm lands and forest properties. 
To date, three large lumber companies own and lease more than 85,700 acres of coal lands. Five commercial mines are in operation and more are to be developed in the near future. In practically all cases where fee lands are leased for mining, the lessee acquires the right to such timber as may be available and necessary for mining purposes.

Recently large coal resources have been provided with rail facilities. This action anticipates extensive future development by one of the large milling companies, as their timber supply is exhausted. Statements of past policy by 22 owners of 329,000 acres of fee lands indicate that timber resources were the major objective when the land was acquired.

The three lumber companies operating coal mines in the two counties now employ about 1,200 men in mine operation, compared to 1,670 in manufacturing forest products. This source of employment has come about since 1928, and the war effort, beginning in 1939, stimulated extensive expansion. One company has experienced a shift of more than 50 per cent of its mill and woods employees to mining. Higher wages in coal production is a strong stimulant. Of course, the older men generally do not find a place in the mining industry, primarily because of age and infirmities. In general, however, coal development appears to be supplanting the lumber industry very rapidly.

In addition to the benefits derived from the expansion of mining, in the form of employment and timber markets, the problem of forest conservation is greatly intensified. Coal leases usually carry a right to all overlying timber essential to mine operations. Obviously, the mine operators have little or no interest in the forests except for the period necessary to exploit the coal. Hence, they have little regard for future forest production. Their cutting practices ignore possible future needs.

Perhaps the mine prop contractors and "scavenger" saw mills catering to the manufacture of other mine timbers are an equally common menace to forest conservation. Timber is purchased by the boundary, usually with a limited time for removal. Contractors, having no long time interest in a particular tract, exploit all timber of any value. The devastation left by this type of forest operator is widely known.

Is is quite generally conceded that regulation of cutting practices in the interest of future production is the solution to this problem. It is of interest to note that Maryland recently has taken a long due forward step in controlling the cutting of timber on private lands. ${ }^{28}$ With the aid of Forest Conservancy Districts, the law provides, among other things, that timber operators "Leave conditions favorable for regrowth;" "Leave (and protect) young growth;" "Arrange for restocking land after cutting;" and generally provides for the protection of forest lands against unnecessary

23 Senate Bill No. 338, Maryland General Assembly, enacted in April, 1943. 
exploitation. ${ }^{29}$ In terms of continued private ownership for forest lands effective regulation of cutting practice may be a partial answer to the serious problems of the past.

\section{Land Policies}

The operating lumber companies own the surface or timber rights on approximately 109,000 acres of which 28,200 will be cut or recut before the industry retires. In the two counties there remain to be cut about 23,800 acres which are virgin except for a selective cutting of the large trees around 1900. This is all that remains of the virgin forests. The total acreage, including the above and good second growth remaining to be cut by the larger mills, is less than 40,000 .

The portable mill operators reported, in general, that they would operate as long as any timber remained. Typical of their answers to questions along this line were these: "Will move wherever logs are available;" "Plenty of props and ties to be cut;" "Will cut as long as timber lasts." Only one or two were planning to quit.

In general, operators expect to dispose of cut-over lands by sale or tax reversion, retaining the subsurface in anticipation of future development. In no instance is there any effort to develop a management program which would look to a long-time or perpetual harvest for supporting a permanent forest industry. Several said that they would be willing to sell cut-over surface for $\$ 3.00$ to $\$ 5.00$ per acre with subsurface reservations. In some instances cut-over lands are being sold in 5- to 40-acre tracts to settlers. This method of disposition has proved unsatisfactory to both the seller and the buyer, in most cases. The seller is forced to repossess in lieu of payment, and the buyer finds public relief the only recourse to a subsistence. The larger holdings which have been closely cut within the boundary of the Monongahela National Forest have been sold to the Forest Service. This has been the most satisfactory method of disposition in the minds of the original owners-provided they are allowed to reserve sub-surface rights.

Individual and corporate land holders (non-operating) have had similar experience, and have similar policies regarding the future. Records from 22 owners of 330,000 acres of forest lands indicate a uniform lack of desire to continue private ownership except where coal is valuable. In such instance surface will be leased if and when coal is leased. Following that, it is of no foreseen value.

A large proportion of private lands probably would be owned by the state at present if the successive tax moratoriums and revaluations of the 1930's had not permitted redemptions at little more than nominal percentages of the taxes levied. Low prices for

29 Forestry, Art. 39-A, Sects. 53 to 64, inclusive, Annotated Code of Maryland (1939). 
stumpage and a lack of continuous income have led owners to feel that taxes forbid continuous private ownership, even since the drastic reductions as a result of tax limitation. The consensus of operators was that a severance or yield tax which is collected when the timber is cut is the only equitable forest land tax, owing to long periods of little or no productivity.

Lack of interest in future surface ownership may be the beginning of serious settlement problems, unless rather stringent regulatory measures are provided, and the rather dense population is provided with alternative opportunities. More or less remote "squatting" is already a serious handicap to welfare and the administration of public services. One of the obstacles to solving the problem of high man-land ratios in the Appalachians is the fact that a large number of prolific families are living so far from public services, with such limited resources, that they do not recognize any alternative to a crude subsistence.

Large acreages of privately owned lands are without adequate fire protection. Owners of one-third of the 329,753 acres for which records were obtained did not belong to the fire protective associations nor did they employ any other type of protection, except the limited service supplied by the state to all lands. This is a very low proportion for the area as a whole because the owners from which records were obtained are those most intensely interested in their property. Many non-resident owners and owners of defunct corporations could not be contacted, but it is known that few belong to the protective organization.

\section{FOREST RESOURCES AND PRODUCTIVITY ${ }^{30}$}

The original intention was to cruise the forests of the three areas from which farm and family living data were obtained, in order to characterize adequately the variations in forest conditions and growth rates prevailing in the central Appalachians. It was possible to complete the forest cruise in only one area-Hacker Valley Magisterial District. In this area, consisting of 51,102 acres, forestry is the major land use. More than 35,000 acres have never been cleared and a large portion of the land once cleared is reverting to forest cover, as indicated by Figure 4.

\section{Forest Types and Growth}

The forests of this area form a very heterogeneous pattern, depending on the character of site. The fact that no single forest type is available in large areas has important implications in the planning of management practices for continuous production of an appreciable volume of any specific type of wood. The fact that comparatively small areas of beech-birch-maple stands are scat-

30 The description and evaluation of forest production was formulated under the close supervision and cooperation of Professors Torkel Holsoe and W. C. Percival of the Division of Forestry, West Virginia University. 

FIGURE 4

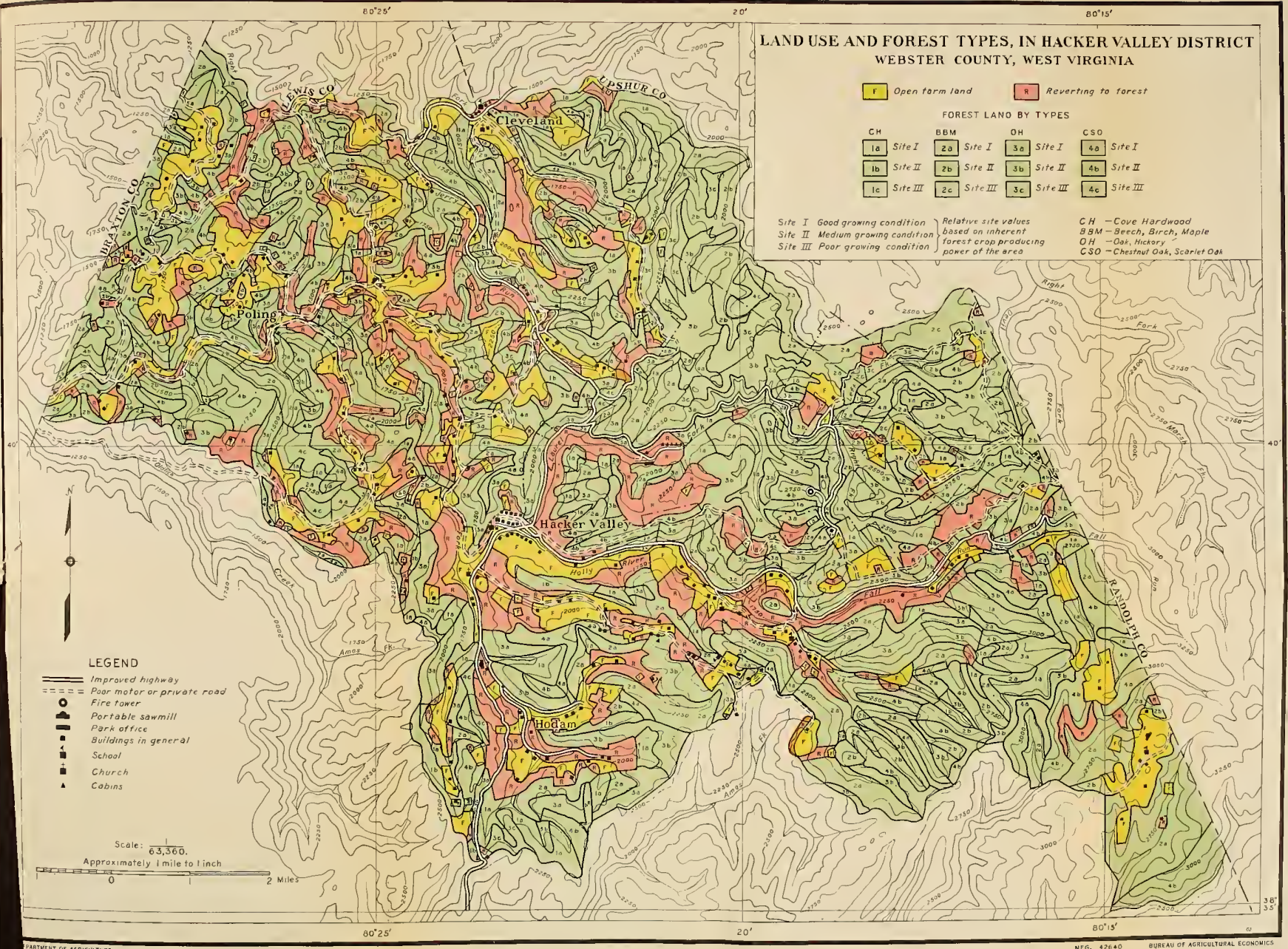


tered over the entire district, for example, means that a management program involving large acreages of this type of production would be more difficult than if larger contiguous acreages of a single type were available. Ownership differences, access to the lands, and the distances involved in harvesting and assembly of timber are only three of the problems that must be recognized in planning forest management in this area. Scattered forest types and the extremely rugged terrain, necessitating high costs for timber removal, are considerations which apparently intensify the desires of operators to clear-cut everything, rather than to practice shortrotation timbering.

The timber cruise indicated that beech-birch-maple (BBM) is the most common forest type in Hacker Valley, with oak-hickory $(\mathrm{OH})$ a close second (Table 19). More than two-thirds of the forest land is represented by these two types, while chestnut oakscarlet oak (CSO) and cove hardwoods ( $\mathrm{CH}$ ) represent the other third. Cove hardwood, particularly yellow poplar, is a preferred type but is small in acreage, and the stands are usually very small in area and scattered widely. Large portions of the old field stands (formerly cleared land reverting to forest) are characterized by fast growing stands of yellow poplar. There are no stands of coniferous trees in this area, although there are some good stands of hemlock, spruce, and pine within the Appalachian ridges.

TABLE 19-Extent of Type Classes in Hacker Valley

District, Webster County, West Virginia

\begin{tabular}{|c|c|c|c|c|c|}
\hline & \multirow{2}{*}{ Type $^{1}$} & \multicolumn{4}{|c|}{ AREA BY SITE 1} \\
\hline & & 1 & 11 & 111 & Total \\
\hline & & acres & acres & acres & acres \\
\hline BBM & .......... & 9,295 & 2,949 & 491 & 12,735 \\
\hline $\mathrm{CSO}$ & $\ldots$ & 2,576 & 4,768 & 552 & 7,896 \\
\hline $\mathrm{OH}$ & (n........ & 4,916 & 4,548 & 956 & 10,420 \\
\hline $\mathrm{CH}$ & . & 4,134 & 720 & 66 & 4,920 \\
\hline All tJ & pes & 20,921 & 12,985 & 2,065 & 35,971 \\
\hline
\end{tabular}

1 Relative site values based on inherent forest crop producing power of the area. (Refer to map-Figure 4).

The composition of the four major types varies from a very high percentage of the major species to a general distribution of mixed hardwoods. The present saw-timber stands of beech-birchmaple, occupying the lower slopes, consist largely of the less desirable beech. In some cases more desirable species were left because of inaccessibility. Consequently, relatively small areas of beech and maple are the principal woods now available for sawtimber. These stands contain from 3,000 to 4,000 board feet per acre at present, and if left uncut would yield from 5,000 to 6,500 in another ten years (Table 20). The present cutting of this type by portable mills is progressing rapidly. The present demand for furniture stock and the general increase in demand for war materials are encouraging the harvesting of this only remaining saw- 
timber of any importance in the district. The annual growth of this type is good on both sites I and II, and the importance of this type of production in possible future management programs should not be overlooked.

TABLE 20-Average Volume of Saw Timber and Pulpwood, per Acre, Hacker Valley District, Webster County, West Virginia

\begin{tabular}{|c|c|c|c|c|c|c|c|}
\hline \multirow{2}{*}{ Type } & \multirow{2}{*}{ Site } & \multicolumn{3}{|c|}{ SAW TIMBER PER ACRE (b.f.) } & \multicolumn{3}{|c|}{ PULPWOOD PER ACRE (cords) } \\
\hline & & 1941 & 1951 & An. Incre. ${ }^{2}$ & 1941 & 1951 & An. Incre. ${ }^{2}$ \\
\hline \multirow[t]{2}{*}{$\mathrm{BBM}$} & I & 4,211 & 6,576 & 236 & 4.7 & -9.7 & .51 \\
\hline & II & 3,783 & 5,688 & 191 & 2.8 & 6.4 & .36 \\
\hline \multirow[t]{2}{*}{$\mathrm{OH}$} & I & 2,303 & 4,296 & 199 & 4.7 & 10.8 & .61 \\
\hline & II & 2,434 & 3,708 & 127 & 3.3 & 8.4 & .51 \\
\hline \multirow[t]{2}{*}{$\mathrm{CH}$} & I & 2,101 & 4,467 & 237 & 5.9 & 14.3 & .84 \\
\hline & $\mathrm{II}^{3}$ & 1,889 & 3,864 & 197 & 3.6 & 9.5 & .59 \\
\hline \multirow[t]{3}{*}{$\mathrm{CSO}$} & I & 1,648 & 2,572 & 92 & 3.0 & 9.1 & .61 \\
\hline & II & 1,987 & 3,067 & 108 & 3.1 & 6.6 & .35 \\
\hline & III & 930 & 1,880 & 95 & 4.4 & 6.5 & .21 \\
\hline \multicolumn{2}{|c|}{ AVERAGE } & 2,783 & 4,568 & 178 & 4.1 & 9.2 & .51 \\
\hline
\end{tabular}

1 Calculated (b.f.) on the basis of volume and growth tables for comparable sites and species constructed for the Cumberiand and George Washington National Forests (Scribners Rule). Cordwood volume and growth calculated from Preliminary Volume Tables For Some of the Tree Species Used for Pulpwood in Preston County, West Virginia, West Virginia Agricultura! Experiment Station, Mimeo. Cir. 37, 1939.

2 Average annual increment $(160 \mathrm{cu}$. ft. cords).

3 Estimated.

Oak-hickory occupies the middle slopes, and is the second most important type from the standpoint of area. White oak, chestnut oak, red oak, red maple, and hickory are the predominant species, with some scattered yellow poplar coming in after the virgin cutting. (Table 21). White and red oak are highly desirable species in this type, while red maple and hickory are of lesser value.

Chestnut oak-scarlet oak is the third most extensive forest type, occupying the shallow stony soils of the ridgetops and extending down the south and west slopes. The growth of this type is slow, largely owing to a lack of organic matter in the soil, and the lack of moisture. Frequent burning has resulted in sparse stands of damaged trees, followed by briers and undesirable species such as sassafras. The fact that more than 23 per cent of the area is characterized by this type of growth is a serious problem in connection with sustained yield management under private ownership.

Cove hardwoods, consisting principally of yellow poplar, basswood and birch, occupy the more fertile soil of the narrow valleys and coves. Although this type represents less than 13 per cent of the woodland in the area, it is the most rapid growing and includes the most desirable commercial species. The annual increment during the next ten years is estimated at 165 cubic feet per acre, compared to about 84 for the chestnut oak-scarlet oak type. A major factor accounting for this difference is the comparatively good 
stands of yellow poplar and basswood that are growing rapidly. The $\mathrm{CH}$ sites are less subject to burning than are the CSO sites which are extremely dry. Cove hardwoods are the most promising for short rotation-sustained yield management; but inasmuch as the area of this type is small and in widely scattered patches, the problem of over-all management is difficult.

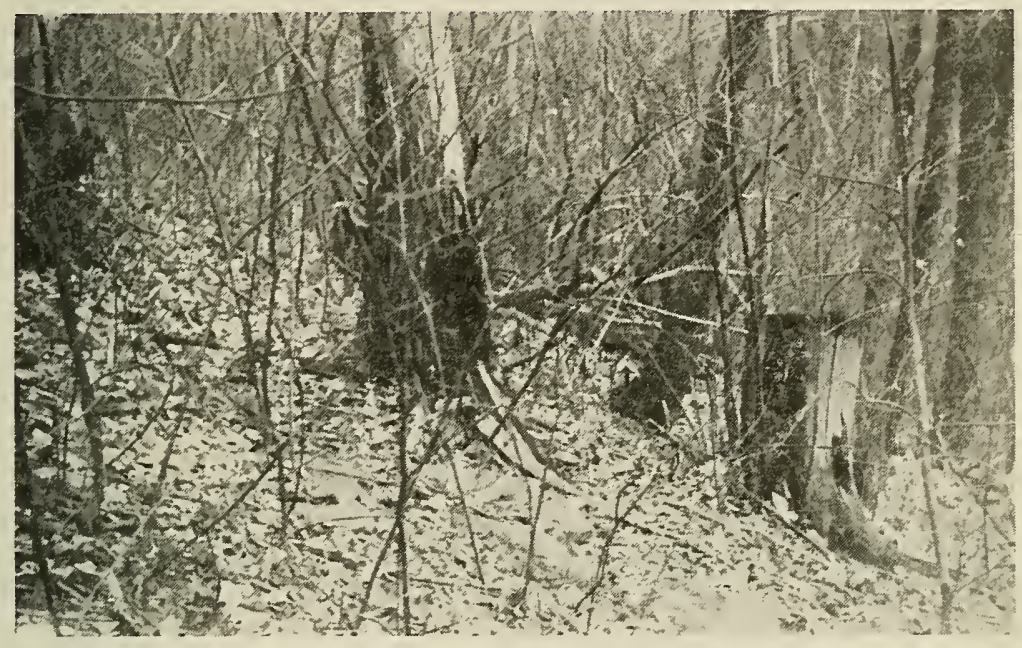

Figures 5 and $6 . \quad A$ dense stand of sassafras brush and severe fire damage characterize large areas of the Chestnut 0ak-Scarlet 0ak type (above). In contrast the dense stand of yellow poplar (below) indicates the greater potential growth of Cove Hardwoods.

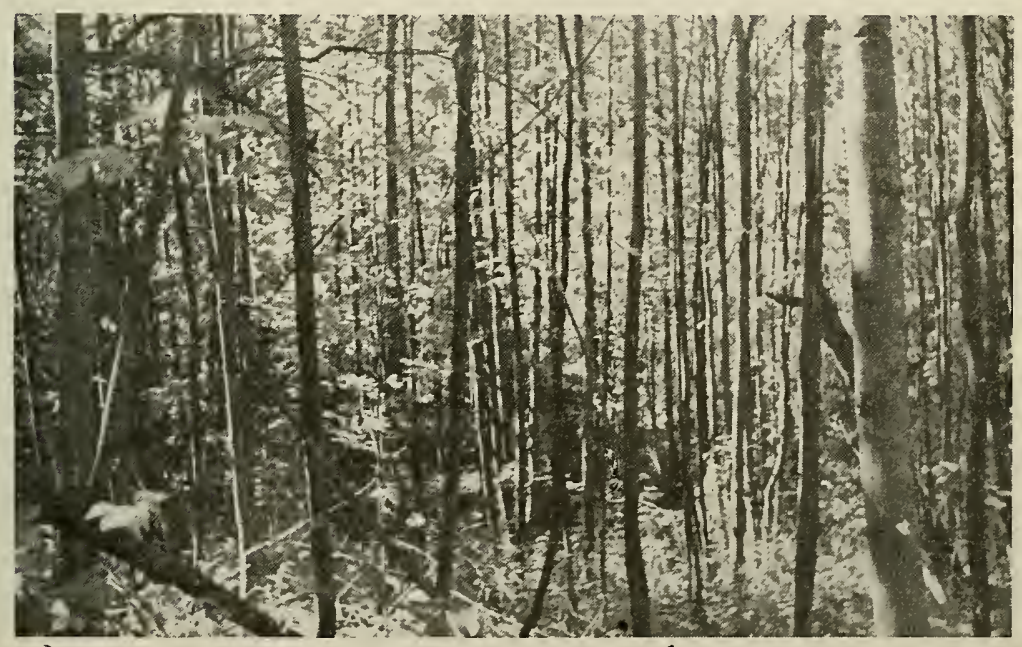


TABle 21-Distribution of Species by Types and Sites,

Hacker Valley District, Webster County

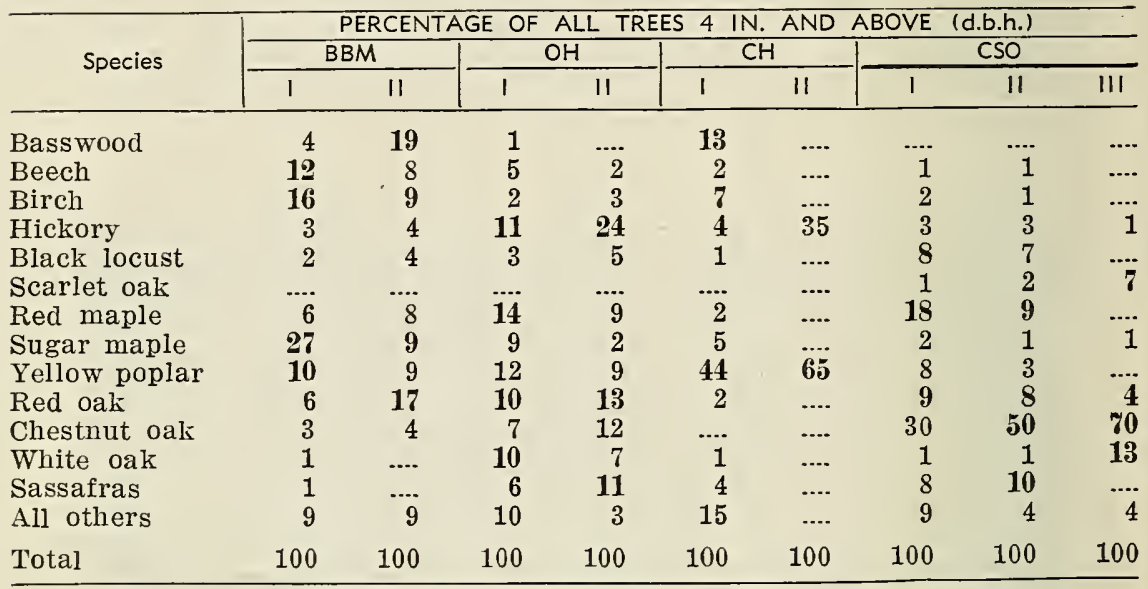

\section{FEASIBILITY OF PRIVATE FORESTRY}

The problem facing the private owner considering forest land investments is extremely complex. Many of the factors influencing potential income are beyond the control of owners, and estimates of future earning power are usually considered even more uncertain than for many alternative types of investment. The length of time involved in forest growth and the consequent indefiniteness of public-private relationships are important considerations. Specifically, the more important items that must be evaluated are: (1) present stands, including volume and condition, by species; (2) growth rates; (3) carrying costs, including taxes, fire protection, and interest charges; (4) future prices; and (5) risks, such as fire, disease, and tax increases. The possibility of large losses from fire and disease is one of the most important considerations because of the impossibility of eliminating all risk at a reasonable cost.

The analysis summarized in Table 22 is an effort to evaluate the potential income possibilities of forestry in Hacker Valley District, taking into consideration the more tangible factors. Rather wide variation in production and value exists between the four major forest types. In terms of the growth over a ten-year period, for example, an acre of BBM (Site I) will produce an average of 0.5 cord of pulpwood and 236 board feet of saw-timber annually. In comparison, the annual yield of CSO (Site I) is 0.6 cord of pulpwood, and less than 95 board feet of saw timber.

On the basis of prices which might reasonably be expected, and average carrying costs, the annual return would vary from 48 to 9 cents per acre for the four major types over the ten-year period. It should be understood, however, that these average annual returns would not be possible immediately, without reducing the 
growing inventory materially. The calculations anticipate an accumulation of growth over a ten-year period, after which it would be reasonable to expect a harvest of this amount. It is necessary to develop a minimum maintenance inventory which will produce an annual volume in accordance with an economical rotation. This minimum inventory exists on only a small proportion of the total acreage at present. Because of this fact, there must be an interim period of inventory accumulation, during which the management program will consist primarily of protection. On that small proportion of the area which now possesses more than a minimum inventory, improvement cutting and thinning are the principal harvests that can be achieved during the ensuing decade.

The stands growing in excess of the average annual increment consist of BBM (Sites I and II), OH (Site I), and CH (Site I). These stands constitute 78 per cent of the total forest area in the district which has never been cleared. In general, these stands now consist of what might be accepted as the minimum inventory, while BBM stands may be selectively cut in certain locations, and improvement cutting might be currently practiced over 60 per cent of this type. There is little that currently can be done on the CSO (Sites I, II, and III) type and the CH (Site II) in the way of a management program, except protection, until the minimum inventory has accrued. In addition, a comparatively large acreage of formerly cleared land now reverting to forest must await the accumulation of a minimum stand before cutting practices can be inaugurated. An exception might be possible whereby thinning during early stages of growth would be economically feasible under intensive forest management.

Obviously, if the cost-price relationship varies from the estimates given in Table 22, the net annual income increment may vary greatly. For example, if the stumpage prices were to be 25 per cent lower than those assumed, with constant costs, the average net annual income increment might vary from 8 cents to 1 cent per acre, instead of from 48 to 9 cents. On the other hand, an increase in stumpage values of this proportion would create a much more favorable basis for private forest practices.

In considering probable future prices, it is worth pointing out that West Virginia forests are located favorably in relation to large areas of relatively dense population. Furthermore, hardwoods are likely to maintain their rather unique position in the fields of residence construction and furniture manufacturing. The enormous expansion of the pulpwood industry in the South and Pacific Northwest may limit somewhat this market for West Virginia forest owners, particularly, if technological developments lead to the economical production of white paper from conifers. However, pulpwood is not the only market in the state, or in Nicholas and Webster Counties, for wood from smaller trees. In fact, on the basis of 1937 coal production, the mines would require roughly nine times the volume of wood that is ordinarily sold for pulpwood in 
the state. Meeting this demand for wood generally has had a detrimental effect on the forests concerned but this need not be the case, provided the demand for mine timber is supplied largely from thinning and improvement cutting, rather than by the premature cutting of all growing stock.

TABIE 22-Estimated Returns per Acre for Ten Years on Average, Best, and Poorest Forest Land in Hacker Valley

\begin{tabular}{c|c|c|c}
\hline I TEM & $\begin{array}{c}\text { Average } \\
\text { for the } \\
\text { area }\end{array}$ & $\begin{array}{c}\text { Cove } \\
\text { Hardwood } \\
\text { Site I }\end{array}$ & $\begin{array}{c}\text { Chestnut } \\
\text { Scarlet Oak } \\
\text { Site III }\end{array}$ \\
\hline
\end{tabular}

Growth in 10 years:

Pulpwood (cords)

Sawtimber (bal. ft.) 1779.0

2366.0

951.0

Stumpage Value ${ }^{1}$ of 10 years growth:

Pulpwood

$\$ 3.06$

$\$ 6.30$

9.46

$\$ 1.05$

Sawtimber

$\$ 8.40$

$\$ 15.76$

1.90

Total

$\$ 6.00$

$\$ 11.00$

Value of Land ${ }^{2}$ (per acre)

Costs for 10 years:

Interest on investment in land la $^{3}$

Taxes ${ }^{4}$

Fire protection ${ }^{5}$

Total

$\$ 10.97$

Net returns per acre for 10 year's

Net returns per acre for 10 years with $25 \%$

lower stumpage prices

$\$ 2.37$

.27
$\$ 4.79$

.85
$\$ 2.08$

$\$ .87$

1 Stumpage values used per cord of pulpwood were $\$ 0.60, \$ 0.75$, and $\$ 0.50$ cents for the area, $\mathrm{C}-\mathrm{H}$ Site 1, and C-S-O Site 111 , respectively. Stumpage values used per M were $\$ 3.00, \$ 4.00$, and $\$ 2.00$ for the area, Site I' and Site 111 , respectively. Wartime conditions have stimulated higher prices for lumber stumpage than those indicated above.

2 Based primarily on normal selling price of land in this area. Theoretically, on the basis of the estimated net returns this land would be valued higher except for the high rate of discount for future income subject to so many risks and uncertainties.

3 Six per cent compounded annually; obviously if buyers obtained credit at lower rates of interest, net returns would be enhanced accordingly. On the other hand, it is doubtful if private credit for forest land purchase can be obtained for 6 per cent.

4 One and one-half per cent of land value which conforms with present tax rates, plus six per cent compounded annually.

5 One cent per acre (per year) does not represent total costs of adequate protection, although this is the present assessment by associations for service to commercial lands. Adequate pratection probably cannot be assured at less than five cents per acre, annually.

The estimated average annual net returns indicated above would appear to justify private investors in rehabilitating and maintaining forest lands. The average annual net return of 24 cents per acre is in excess of an assumed 6 per cent charge for capital investment, representing a return for risk and management over and above all costs. However, practically all owners contacted indicated that they had no intention of holding the land for future forest harvests.

Apparently, the time period involved during which little or no income is available, but during which costs are continuous, plus the risk which cannot be covered by necessarily limited fire protection, together with many uncertainties of the future, discourage 
private owners from returning a portion of their capital earnings to forest production in preference to alternative types of investment. Undoubtedly, part of the reluctance to invest in forests is due to the tendency to think in terms of exploiting forests as they would the strictly exhaustible mineral resources. However, the results are none the less real.

\section{Employment and Population Adjustments}

Forest resources offer less and less opportunity for employment under present methods of utilization, and to the extent that mining fails to employ the more than 3,000 employable workers in two counties who were unemployed in 1940,31 there is need for additional work opportunities or for adjustments in the population. A brief analysis of the possible employment in Hacker Valley District, even after a 10-year period of forest rehabilitation, indicates limited opportunities in forest industry. The forest cruise indicated a possible annual production of approximately 5,874,000 bd. ft. of saw timber and 16,830 long cords of pulpwood from 33,000 acres of land now in forest. These data anticipate a ten-year period of growth in addition to the inventories existing in 1941. It is estimated $^{32}$ that under private commercial management and operation the harvest and milling of 5,874,000 feet of lumber will give full employment to about 82 workers. In addition, the harvest and delivery of 16,834 cords of pulpwood will occupy 108 workers. In view of the importance of the pulpwood markets in providing employment, it is important to recognize that pulpwood is obtained largely from improvement cuttings. Therefore, if this market were not available, it could not be assumed that even part of the 108 workers would find employment in cutting saw logs instead of pulpwood; and the production of mine props and ties would employ only a few more than sawtimber, although the cutting cycle would be shorter. The above estimates of man years are based on a work year consisting of 250 days which leaves time for the worker to produce at least part of the food required for his family. Assuming that lumber and pulpwood would be the marketable types of harvest, these data indicate that there would be employment on a sustained basis for approximately 190 men. In comparison, data obtained for this district indicate that there were approximately 284 families in the same area which were unemployed or seriously underemployed. ${ }^{33}$ The heads of 46 per cent of this total number of households were over 50 years of age. There were also 108 sons in the area over 18 years of age at home.

311940 Census of Occupations.

32 For harvesting and milling $1,000 \mathrm{bd}$. $\mathrm{ft}$. of lumber:

2.5 man days for cutting and delivery to mill pond;

1.0 man days for milling.

For harvesting and delivery of one cord of pulpwood:

1.3 man days for cutting and preparation;

0.3 man days for hauling.

These standards are consistent with experience gathered by the West Virginia Forest Products Association.

33 That is, there were 284 families with annual gross incomes from all sources (except relief) of less than $\$ 500$. 
Therefore, assuming a constant number of families (present number-72) receiving more than $\$ 500$ gross cash income, and that future forest production would fully employ an additional 190 families, ${ }^{34}$ there remain 94 families not provided with employment in the forests, plus 70 sons over 18 who were still at home in 1941 . The remaining 38 older sons are assumed to replace as many family heads over 50 years of age within the area which received more than $\$ 500$ gross cash income. An additional 150 boys under 18 years of age will be growing into the labor force during the ensuing decade. 35

This means that at best the potential employment of this area, after rehabilitation, could support only 75 per cent of the family units now in the area. Furthermore, the children of the families remaining in the area, in excess of replacements, will be forced to seek employment elsewhere if reasonable levels of living are to be attained.

A big problem is what this labor force, for which the forest resources offer potential future employment, is to do during a tenyear or longer period of forest rehabilitation. Furthermore, conservation measures may not be effected soon enough to prevent the requisite period of rehabilitation from being lengthened considerably.

In a large measure, man-land adjustments can be accomplished by closing out low income homesteads by public purchase, and by rural land use zoning after the death of present aged people and the discontinuance of present uses. Moreover, it is highly probable that appreciable numbers of those now employable, and those children who will be growing into the labor force, will be forced to leave these areas in order to be fully employed. Vocational training and greater attention to physical fitness should aid this adjustment greatly. Many of those who remain in the area might take advantage of vocational training in order more adequately to-fit themselves for industrial and service opportunities therein.

In addition to the need for reduction in the present population, the amount depending largely on future development of mining, there is also the need for adjustment in the location of the people remaining in the predominantly forest areas of central West Virginia. Large numbers of occupants, owners as well as squattertenants, are now located "far into the woods," inaccessible except for a path. All types of public service are difficult and costly, and some desirable services cannot be made to reach them. Special effort should be exercised toward relocating, over a period of time, all land occupants near the better roads which have been provided during the past decade. Public assistance for aiding employable and unemployable people to relocate would probably be a justifiable

\footnotetext{
31 The amount of employment in farest industry by those families receiving over $\$ 500$ was assumed to offset the employment in non-forest industries by those families receiving less than $\$ 500$ gross income.

35 A similar number of girls of all ages are potential migrants to fuller employment.
} 
investment from the standpoint of both costs and returns. Certainly, there should be some safeguard against additional or repeated remote and isolated settlement in the interest of the most desirable land use, as well as human welfare. Before zoning of this character will be feasible, local government, along with that of the state, must recognize the atrocities of present settlement patterns and the need for adjustment.

\section{FEASIBILITY OF FOREST-FARM HOMESTEADS}

The problem of a rather dense population on the small amount of land suitable for farming in a predominantly forest area demands a study of some feasible procedure for utilizing both human and forest land resources. In so far as the people are concerned, there are two possible alternatives: (1) to remove them from forest areas; or (2) to maintain all or a portion of them in their present locations by providing economically practicable forest operations; or by subsidizing them in order to attain an acceptable level of living and welfare.

It is recognized that many of the employable people now depending on low quality agricultural resources and some part-time employment are underemployed. At the risk of criticism from advocates of "full employment," together with the assumption that some people will remain in this and similar areas and perhaps be needed if forest resources are to be rehabilitated and maintained, the next step in the analysis will be to test the feasibility of forestfarm homesteads under private property.

The development of homesteads of this type is dependent on many factors, the more important of which are: (1) the number of people dependent on the land, (2) the acreage of land available which is suitable for self-sufficing farming, (3) amount of employment and income available from forests, and (4) the accessibility of the lands and the possibility of organizing economical forest enterprise units. To provide specific information on these points a small area on Hodam Creek was selected for intensive study. At the time of the field survey there were 19 families living in this area, which consists of approximately 3,354 acres of forest land, 195 acres of cropland, and 383 acres of pasture, as currently used. Of the 19 families, one had no employable members because of old age, and three were temporarily employed in connection with a portable sawmill, leaving $\mathbf{1 5}$ at least partially dependent on land resources. Two of these had sufficient employment to maintain an acceptable level of living. The remaining 13 were dependent on relief to a large extent, owing to the scarcity of suitable farm land and forest or non-farm employment.

This community is near a paved road, with a one-room primary school nearby, and a bus route to a high school 18 miles distant. Public services, therefore, will not be a major problem. The amount of land available for crop production is a limiting factor, in terms 
of establishing a minimum subsistence unit as a part of a forestfarm homestead.36 Only three of the existing family units had access to as much as 9 acres of cropland and 12 acres of pasture. Eight had approximately half enough cropland, and four had only enough for a garden.

An appraisal was made of all land to determine the amount suitable for crops and grazing, and it was estimated that approximately 70 acres were available and that adequate pasture is available for maintaining a subsistence livestock enterprise. If all the land suitable for crops were equally divided into units of an adequate size there would be enough for only eight families instead of the 19 that were living in the area. Since only three families now have adequate cropland for a subsistence unit at their disposal, it is apparent that a redistribution of crop and grazing land would be necessary in order to provide the minimum for eight families. This would leave more than half the families without any land. In other words, in so far as subsistence farm enterprises are concerned, more than half of the people would have to be relocated in other areas or be provided with employment not dependent on land resources.

Thus far, no cash income has been foreseen for the eight families which might have sufficient land from which to obtain their food perquisites and shelter. They must depend on the forests for essential cash income in lieu of other lucrative employment. According to data obtained on land holdings, only two of the 19 units include as much as 100 acres of forest land. In all, the present holdings include 767 acres of forest land, consisting of land which has never been cleared and that which is reverting to forest cover. The remaining 1,767 acres are owned in larger tracts by nonresidents and interests of large timber operators. In order to provide access to adequate forest operating units, adjustments in the present tenure pattern would be necessary.

A feasible operating forest unit, as a source of cash income in conjunction with the subsistence farm, will depend on the productivity of the forest and the time (labor) available per family. The data in Table 23 indicate the annual increment that may be expected from the four major types of forests in the Hodam area. Inasmuch as each type is scattered in small patches throughout the area, it must be assumed that any operating unit would likely include most of the types and sites. Hence, a weighted average increment is more or less suitable for estimating probable yields and labor requirements.

It is estimated that of the twelve months at least three will be required of the homestead operator for tending to food production, caring for fire lines and trails, and other maintenance duties. This

36 The minimum average amount of farm land required per family was estimated to be nine acres of cropland and 12 acres of pasture, for the production and maintenance af 500 pounds of pork, 25 hens, 40 young chickens, one cow, and one horse, plus one acre for garden and fruit. 


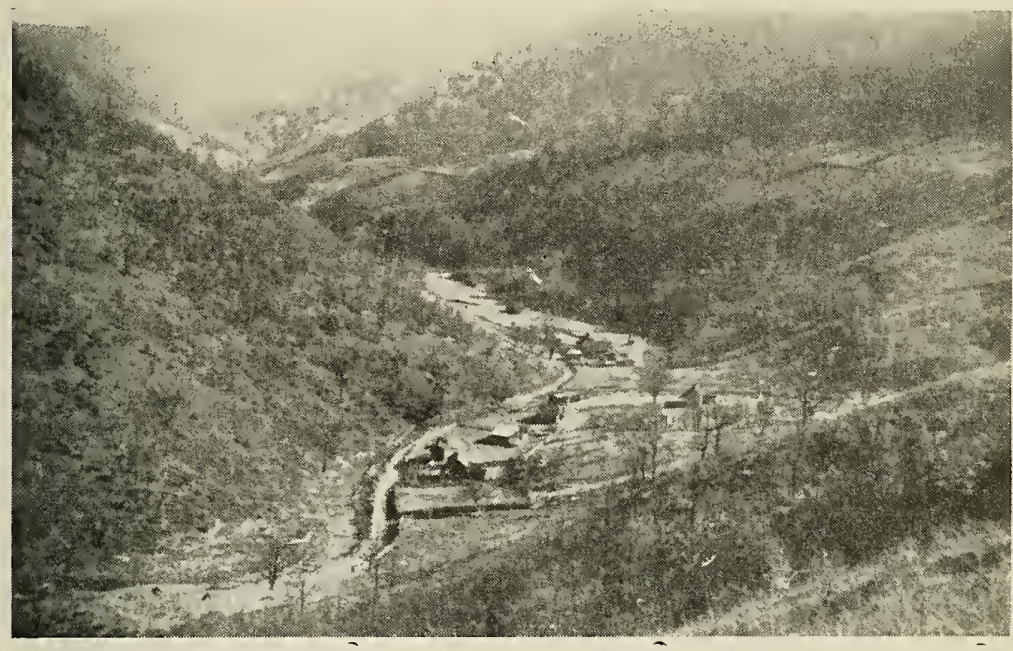

Figure 7. Instead of the four units now located in this narrow valley, there may be adequate cropland for two subsistence units, if forest resources were available and accessible for supplying adequate cash income. The extremely steep hillsides formerly cropped are suitable only for forestry and some grazing. There is scarcely enough land in the bottoms for food production.

leaves a maximum of 225 working days for forest operations. On the basis of an estimated ten-year rotation, starting ten years hence, it is apparent that an average annual increment of .38 cord of pulpwood, or the equivalent in props, and 287 board feet of saw timber may be harvested per acre. A conservative estimate of the

Table 23-Average Annual Increment per Acre by Forest Types and Sites, Hodam Area, Webster County

\begin{tabular}{|c|c|c|c|c|c|c|c|c|}
\hline \multirow{2}{*}{ Type } & \multirow{2}{*}{ Site } & \multirow{2}{*}{ Acres } & \multicolumn{2}{|c|}{ PRESENT VOLUME } & \multicolumn{2}{|c|}{$\begin{array}{l}\text { AVERAGE ANNUAL } \\
\text { INCREMENT }\end{array}$} & \multicolumn{2}{|c|}{$\begin{array}{l}\text { VALUE OF } \\
\text { INCREMENT } 1 \\
\end{array}$} \\
\hline & & & Sawtimber & $\begin{array}{l}\text { Pulp- } \\
\text { wood }\end{array}$ & Sowtimber & Pulpwood & Sawtimber & $\begin{array}{l}\text { Pulp- } \\
\text { wood }\end{array}$ \\
\hline \multirow[b]{2}{*}{ BBM } & & & $b d . f t$. & cords & $b d . f t$ & cords & dollars & dollars \\
\hline & $\begin{array}{r}\text { I } \\
\text { II }\end{array}$ & $\begin{array}{r}645 \\
34\end{array}$ & $\begin{array}{l}3,608 \\
2,372\end{array}$ & $\begin{array}{l}6.7 \\
4.7\end{array}$ & $\begin{array}{l}302.9 \\
215.6\end{array}$ & $\begin{array}{l}.35 \\
.38\end{array}$ & $\begin{array}{r}1.21 \\
.86\end{array}$ & $\begin{array}{r}0.26 \\
.29\end{array}$ \\
\hline $\mathrm{OH}$ & $\begin{array}{l}\text { I } \\
\text { II }\end{array}$ & $\begin{array}{l}294 \\
702\end{array}$ & $\begin{array}{l}2,303 \\
1,815\end{array}$ & $\begin{array}{l}4.7 \\
4.8\end{array}$ & $\begin{array}{l}199.3 \\
188.4\end{array}$ & $\begin{array}{l}.61 \\
.42\end{array}$ & $\begin{array}{l}.60 \\
.57\end{array}$ & $\begin{array}{l}.31 \\
.21\end{array}$ \\
\hline $\mathrm{CH}$ & $\begin{array}{r}\text { I } \\
\text { II }\end{array}$ & $\begin{array}{r}417 \\
83\end{array}$ & $\begin{array}{l}3,092 \\
2,492\end{array}$ & $\begin{array}{r}10.6 \\
7.6\end{array}$ & $\begin{array}{l}581.9 \\
469.0\end{array}$ & $\begin{array}{l}.19 \\
.14\end{array}$ & $\begin{array}{l}2.33 \\
1.88\end{array}$ & $\begin{array}{l}.14 \\
.11\end{array}$ \\
\hline CSO & $\begin{array}{r}\text { I } \\
\text { II } \\
\text { III }\end{array}$ & $\begin{array}{r}182 \\
125 \\
31\end{array}$ & $\begin{array}{l}3,485 \\
1,700 \\
1,458\end{array}$ & $\begin{array}{l}1.8 \\
3.9 \\
3.9\end{array}$ & $\begin{array}{r}103.4 \\
193.5 \\
98.2\end{array}$ & $\begin{array}{l}.69 \\
.24 \\
.28\end{array}$ & $\begin{array}{l}.21 \\
.39 \\
.20\end{array}$ & $\begin{array}{l}.35 \\
.12 \\
.14\end{array}$ \\
\hline \multicolumn{2}{|c|}{ Average } & $(2,513)$ & $2,684.8$ & 6.1 & 287.0 & .385 & 1.03 & .24 \\
\hline
\end{tabular}


number of eight-hour days required for all the operations in connection with this harvest would be 11.5 days per acre. ${ }^{37}$ With about 225 days available, each unit operator could manage 20 acres annually; or on the basis of a ten-year rotation, 200 acres would constitute the maximum operating unit.

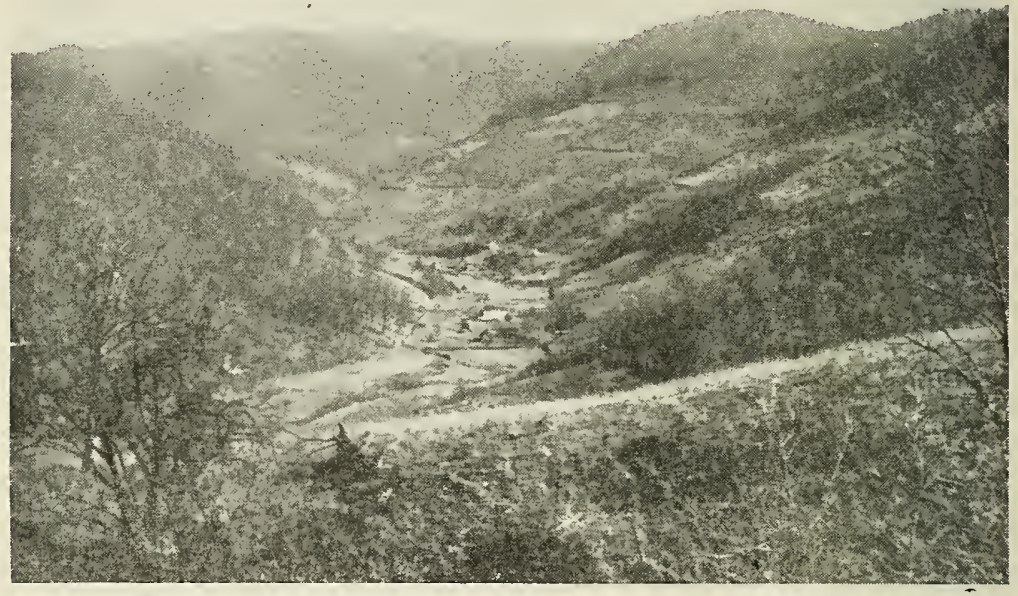

Figures $S$ and 9. (Above) One of the units now possessing sufficient farm land for a subsistence unit. The hillsides revert quickly to forest cover if left undisturbed. Yet many years must elapse before any income will be forthcoming. (Below) i more nearly adequate site for a forest-farm subsistence unit, with access to both forest and farm land, situated on a hard road.

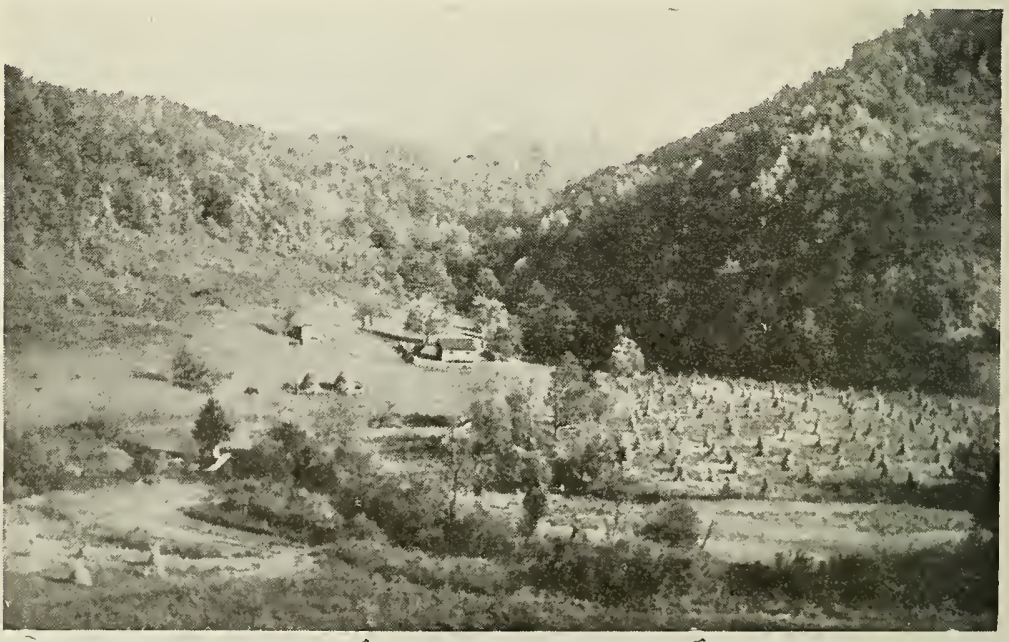

37 About five days would be required for cutting, peeling, skidding, and stocking 3.8 cords of pulp, and 6.5 days would be required for cutting and skidding 2,870 board feet of saw logs. This is conservative because of the rough, steep terrain over which the work must be done, together with inclement winter weather. 
On the basis of the forest land available within a reasonable distance of the valleys where homesteads might be located, there is adequate forest land available to allow at least 12 units; while suitable farm land is available for a maximum of only eight units. In fact, taking the whole of the surrounding territory, the proportion of suitable farm land is so small that forest-farm homesteads could be planned to include only a small portion of the forest land, regardless of their feasibility.

\section{Forest Income and Costs}

Forest income would be derived from stumpage (29 per cent) and the labor involved in harvesting (71 per cent). The probable weighted average prices obtainable for stumpage were estimated at 62 cents per cord of pulpwood, and $\$ 3.61$ per M for saw timber. The calculated return from pulp stumpage for 20 acres is $\$ 47.74$. The labor income for harvesting 77 cords of pulpwood is estimated at $\$ 269.50 .38$ Similarly the annual stumpage return from the saw timber increment on 20 acres would be $\$ 207.21$; and the labor income from cutting and skidding 57.4 M board feet of saw timber would be $\$ 344.40 .39$ Thus, the total annual gross return from a 20 -acre unit would approximate $\$ 868.85$. It is again recalled that this return is based on the assumption that the present stand inventories will be enhanced by ten years' growth before cutting practices are begun, and that markets will be available for the timber to be harvested. 40

The above estimates are considered the maximum annual gross income. In order to carry out this work schedule the operator of each unit would be fully occupied the year around, more fully than a large percentage of the present residents are accustomed to. Adding to the difficulties of achieving a working schedule of this intensity are severe winter weather and extremely rough terrain. This area receives an annual precipitation of 60 to 70 inches, a substantial portion of which falls as snow, accompanied by low temperatures of varying duration. Even during the most favorable weather the rough topography serves as a stubborn obstacle to logging operations.

The costs chargeable against an operating unit of this type are largely overhead or capital costs. It is assumed that by some arrangement a redistribution of both the forest and farm land could be achieved, whereby 21 acres of farm land and 200 acres in proximity could be made available to eight families. It is further assumed that the present equity in real estate could be arranged to

\footnotetext{
3s Pulp stumpage: $3.85 \mathrm{cds}$. per acre x 20 As.777 cords@.62-\$47.74.

Labor:77 cds. @ \$3.50-\$269.50 (Total-\$4.12 per cord).

38 Saw timber stumpage: 2,869 board feet per A.x 20 As.-57.4 M @ \$3.61-\$207.21. Labor:57.4 M@\$6.00-\$344.40 (Total-\$9.61 per M).

40 Labor requirements for cutting, peeling, skidding, and stacking pulpwood-11 man hours per cord $-\$ 3.50$.

Labor required for cutting and skidding 1,000 bd. ft. of saw timber - 16 man hours per $\mathrm{M}-\$ 6.00$.

Both operations assume two men cutting together with team. Returns from stumpage and labor are within the limits of probable future prices for cordwood and logs skidded to a loading point.
} 
cover the acquisition of the required crop and pasture land (22 acres for $\$ 330$ ) through partial or total sales and exchanges. Inasmuch as farm land is available for only eight units, it will be necessary to eliminate 11 of the 19 existing inadequate units, except in so far as they may be able to obtain income from other sources.

In order to have acceptable dwellings, water supplies, and other facilities, it is reasonable to assume that a minimum investment of $\$ 1,000$ would be required, in addition to the existing facilities. A forest unit of 200 acres at $\$ 6$ per acre, which is consistent with current assessed values, would require an investment of $\$ 1,200$. The investment in homestead improvements and forest land of $\$ 2,200$, at four per cent interest, would require $\$ 162$ annually for amortization over a 20-year period. Local real estate taxes would require $\$ 25.30$ annually, on the basis of a $\$ 2,530$ investment at the maximum rate applicable to Class II property of $\$ 1.00$ per one hundred dollars of actual value. Fire insurance on buildings would approximate $\$ 6.00^{41}$ annually. Thus, the total annual requirements for carrying this minimum investment would be approximately $\$ 193.30$, exclusive of any charge for livestock, equipment, and maintenance. This amount would be chargeable against the gross cash income from forest production, which was estimated to be $\$ 868.85$, resulting in a net return to labor of $\$ 675.55$ for family living and maintenance costs. ${ }^{42}$

Considering the fact that a large percentage of the food should be produced from the self-sufficing unit, and in view of the general low income level of many families at present, the return of $\$ 676$ appears to be a reasonable and acceptable income per family unit. On the other hand, this income is predicated on several more or less untried and uncertain factors. (1) It is assumed that a pulpwood and timber market will be available. The future pulpwood market for hardwoods is somewhat uncertain because of the competition with southern softwoods. If this type of growth must be sold in the form of mine props, the return would probably be cut more than half. Operating units of the suggested character are dependent on some type of short rotation cutting. Pulpwood appears to be the only possibility that will furnish this, along with a relatively high labor return. Another factor which makes pulpwood preferable over mine props is the fact that pulpwood cutting can, to a larger extent than is true of mine props, be an improvement cutting in the interest of more valuable saw timber stands over a longer period. (2) This volume of income is dependent on nine months of intensive effort, and it is doubtful if the people for whom such

41 Units of this size within 11/2 miles of the residence of the owner are not assessed one cent per acre for fire protection. Chapter 20, Article 9, Sections 12 and 13, Code of West Virginia, revised to March 11, 1939. In any event, adequate protection would cost more than this amount.

42 It is possible that the cooperative use of labor-saving machinery might aid in operating a larger acreage, with a resulting larger annual family return. This would involve higher interest and depreciation costs, and it is questionable whether greater capital costs can be justified under conditions likely to prevail a decade hence. No allowance has been made for possible earning ability of family members other than the operator. Obviously, additional labor would facilitate the operation of larger acreage units. These factors, however, do not modify the necessity of a significant period of rehabilitation. 
homesteads are designed have the "drive" to achieve this work intensity. This is particularly true when considered along with the inclement weather of the winter months. (3) Whether the estimated potential income is to provide a satisfactory level of living depends on the frugality and thrift of the recipients. It would be ample for many self-sufficing European peoples who have techniques and habits essential to frugal living. This level of income is still of a subsistence character, however. It could not be expected to supply more than the bare essentials of an average family, living in a commercial economy. Luxury items such as automobiles, advanced education, and travel would not be possible. For this reason alone, this level of subsistence living could not be justified if better alternative opportunities were available. (4) This entire scheme is predicated on the assumption that some arrangement could be possible to reduce the present population to the number which the land might support, and then to support the reduced number during a period of at least ten years during which the forest resource could be rehabilitated to an income-producing status. The reduction of the population involves three major considerations: (a) The adjustment would have to be facilitated by some public agency which would purchase all or most of the land and redistribute it by sale to the families selected to own it, in order to achieve satisfactory operating units. (b) Aged and otherwise unemployables, supported by the public, would require a satisfactory home, preferably through the provision of a life lease. (c) The excess younger people on the land at present and those of following generations should be provided with essential vocational training which would enable them to obtain employment in mining and industry. By such a plan, population might gradually be adjusted according to the productive capability of the resources. This is just the start of the rather complicated program which would be necessary.

The support of the reduced population during the period of forest rehabilitation is a major obstacle to the establishment of this plan, unless a program of public works for capital improvement could be justified on the basis of depressed economic conditions resulting in the lack of alternative opportunities, and it is extremely doubtful if sufficient productive work could be found in connection with adjacent land resources to provide justifiable employment for more than one year. The only subsidized work that would be feasible during this interim period is that of building fire trails (combination fire and $\log$ roads) and lines, and setting the self-sufficing farm unit in order.

It is estimated that the building of the necessary fire trails and lines to serve the 1,600-acre tract would require only 396 man days, or less than 50 days work for each of the eight families. Other capital improvements that might be made to homesteads and facilities would certainly not require more than the remainder of one year. Consequently; public works employment would occupy the eight operators only a single year. 
In addition, the improvement and selective cutting that might be done during the first ten years was estimated to consist of harvesting about 2,354 cords of pulpwood and 1,863 thousand board feet of saw timber from 982 acres. The remainder of the forest land has no timber that might profitably be removed during the next decade ${ }^{43}$ without reducing yields materially over the longer period. From this limited cutting, the eight operators should be able to realize a gross return of $\$ 18,835$, or an average annual gross return of $\$ 235$ per unit over the interim period of ten years. Obviously, the cutting of this small amount would employ the eight operators only a small portion of the time if it were to be spread over the entire period.

The average annual gross return of $\$ 235$ is only slightly in excess of the annual carrying costs of the investment $(\$ 193.30)$. Thus, there appears to be no adequate source of income by which to support the family units during the ten-year interim period. Consequently it is not apparent that the forest-farm homestead plan would be satisfactory in relieving the underemployment of forested areas in this section of the Appalachians. It is generally agreed that growing conditions are better in Webster and Nicholas and adjacent counties than in most other parts of the mountain area. Hence, it is rather certain that to rule the plan out for this area is to do the same for the entire region. This conclusion does not preclude the possibilities of residents owning subsistence homesteads but depending for employment on the larger commercial forest tracts for the necessary cash income provided these tracts were so managed that continuous employment were available. However, for a time following the almost complete exploitation of timber inventories, the foregoing analysis indicates that commercial woodlands are not suitable for private ownership at the prevailing carrying costs and with the prevailing risk involved.

\section{IMPLICATIONS}

This analysis of present and potential resource utilization in Nicholas and Webster Counties involves both people and land. The desirable adjustments in neither can be determined without consideration of the other. The number of people that may be supported at an acceptable level in the future depends on the extent to which all resources can be made to provide employment. In this study the center of concern has been that of forest resources. The implications of the several findings of the foregoing analysis are important considerations in the determination of what type of forest land tenure will be feasible in the future, and the desirable relationship of public interests to land resources.

4:3 Additional cutting could be made before the expiration of ten years, but this would reduce the growing inventory, and yields at the later date would be lower accordingly. Hence, in order to look forward to an economically feasible harvest at a later date it is necessary to allow an accumulation of growing stock. Moreover, present stands are being recut in response to wartime price stimuli, and before such a program could be effected, it is probable that little will remain as a basis for a program of selective and improvement cutting. 
The evaluation of forest production indicated that in so far as the assumed costs and returns were concerned forest lands are basically productive, although the present state of depletion may forestall economical harvest and the estimated long-period earnings may not be as high as would be possible from alternative types of investment. On the other hand, present owners apparently are not interested in retaining their lands for future cutting following the removal of present stands. They have willingly sold large acreages of cut-over forest land to the United States Forest Service and other public agencies. Furthermore, without exception, the owners have indicated a desire to rid themselves of cut-over lands, except when they may be of value in coal development, and in no instance has an owner in Nicholas or Webster County developed or practiced a program of sustained forest production to date (1941). Subsidies for improvement practices and plantings by the Agricultural Adjustment Administration failed to interest farm owners of forest lands in developing rehabilitation programs.

The logical question, then, is why are timber operators and landowners disinterested in long-time forest management? Farmers are not in a position to think in terms of long-time forest conservation. The need for income has long ago led most of them to dispose of all merchantable timber, and only a few farmers own sufficient woodland for an adequate operating unit. Owing to these factors there is little or no relationship between the utilization of agricultural and of forest resources at present.

Receivers of defunct corporations, administrators of many woodland estates, and owners of other cut-over lands are forced to realize some income at frequent intervals to cover taxes while they wait and hope for mining to be developed or gas to be found. They look to meager forest resources to cover these carrying costs. What remains of the woodland is merely complementary to potential subsurface exploitation. Currently operating timber owners aim to realize the greatest possible annual returns, assuming that there will be alternative types of enterprise when timber is gone. For example, the higher prices of recent years prompted one large mill to supplement its cut by installing a smaller mill for facilitating rapid removal of timber. In fact, the provisions of timber sale contracts with time limitations, have encouraged this practice.

The decision by an operator to liquidate timber resources is not necessarily an indication that sustained yield forest management will not produce returns in excess of costs. It may be a matter of satisfying owners with the greatest possible earnings at present; or it may be a matter of alternative higher earnings which exceed the anticipated earnings from sustained forest production. In such cases "opportunity cost" is the determining factor. Thus the degree of profitability may alter a landowner's decision to grow or not to grow timber. This would be true regardless of public control. Public control over private property in the interest of social wel- 
fare would necessarily anticipate profitable private operations. If this is not true, public ownership is the only alternative.

The preceding analysis of forest production in Hacker Valley indicated that forest lands in the area are basically profitable, in terms of the assumed cost and return relationships. This is to say that forest lands are sufficiently productive to justify the costs thereof, over a ten-year period. On the other hand, at least three important facts are not apparent in Table 22. (1) An average annual return of 24 cents per acre, above all costs, may not attract investors if alternative opportunities offer higher profits. (2) Fire and market risks over comparatively long growing periods are great, and forest owners have been provided with no adequate coverage for these risks. (3) The returns indicated represent potential harvests following a rehabilitation period of ten years, or longer, during which cut-over lands would be allowed to accumulate a merchantable inventory. In order to foresee the possibility of continued private ownership it will be necessary to eliminate certain institutional barriers and possible ignorance regarding the potential earnings of forest lands.

It is entirely possible that an educational program designed to give forest owners information regarding the potential value of long-term forest management would interest many in rehabilitation and conservation. ${ }^{44}$ Education is fundamental. Institutional inducements, and subsidies will have little permanent influence unless owners are familiar with the essentials of long-term management, and appreciate the income possibilities. In the past, educational efforts have not reached effectively most commercial operators. It is possible that an educational program may need to be supplemented by statutory regulations establishing minimum standards to be followed in timber harvesting in order to prevent needless waste and destruction. Information obtained from forest owners clearly indicates that it would be a mistake to depend entirely on education for solving the problem of rehabilitating and protecting forest lands. Risk, the demands for income, and the costs of waiting cannot be eliminated or satisfied by education.

In the interests of continued private ownership some revision in forest taxation may be in order. A number of owners suggest a severance or yield tax for replacing present ad valorem levies. This is an easy way out for them, since most of the timber is already cut. Advocates of the yield tax are looking for a measure which

\footnotetext{
44 A significant beginning has been made in this direction by several organizations. One of these is the West Virginia Forest Products Association. For a discussion of this organization see Percival, W. C., Cooperative Woodland Management and Marketing-an Essential Part of a Complete Land-Use Program. Journal of Forestry, December, 1942, pp. 944-47; also Percival, W. C., Cooperative Woodland Management in West Virginia. West Virginia Farm News, October, 1942, P. 3. The operations of this association include Webster County. During 1941 Nicholas County was organized as a Soil Conservation District. The program of this organization, among other things, includes technical education and assistance for conserving forest resources. Work in cooperative farm forestry administered by the Soil Conservation Service and the State Conservation Commission under the authority of the Cooperative Norris-Doxy Farm Forest Act is making progress in the two adjoining counties of Lewis and Greenbrier. In addition to general educational work, the Division of Forestry, West Virginia State Conservation Commission, is sponsoring Fire Protection Associations which are active in Nicholas and Webster Counties.
} 
would encourage private ownership by reducing or eliminating tax costs over the long period of regrowth. Although present taxes may not appear excessive, it is important to observe that an annual tax of 10 cents per acre, with compound interest at 5 per cent, grows into an investment of $\$ 12.08$ per acre over a 40 -year period. It would probably not be desirable to eliminate the ad valorem levies, but a reduction of 75 to 90 per cent would undoubtedly lend incentive to protection and rehabilitation by private owners. ${ }^{45} \mathrm{Al}$ though this would involve a drastic revision in the sources of local public revenue, it is quite apparent that even greater revision would be necessary if the land should be forced into public ownership.

Adequate fire control is another paramount need if private ownership is to be feasible. The risk of fire must be reduced greatly if a private owner is to be interested in long-range forest management. In addition to destroying growing stock and soil humus, the present risk of fire leads owners to cut their woodlands prematurely rather than bear the risk of complete destruction by fire.

Although the number and extent of fires has been reduced in recent years the loss is still excessive. Education plays an important part in an adequate fire control program but it must be supplemented by an efficient fire fighting organization. The establishment of such an organization in West Virginia depends on the general recognition of two factors: first, that technically skilled men are required to direct the fighting of fires; second, that investment in an adequate fire control program is distinctly profitable and therefore the appropriations for this purpose should be increased. In connection with this last point it is questionable whether the state should follow the practice of charging certain owners one cent per acre for fire protection, which is much less than the actual cost incurred, instead of adopting a policy of providing adequate protection to all landowners without making any special charge. Logically the owner might be expected to pay all the costs of preventing and fighting fires on his property but since few would do so the state should assume the responsibility for all owners because of the many benefits to the public from adequate protection. Forest fire insurance would doubtless be of value to some owners. Limited experience with this type of insurance proved successful in New England but the business has not expanded. ${ }^{46}$ Furthermore, the cost would be prohibitive unless fires were kept at a minimum through an efficient organization.

A further requirement of private forest enterprises is the availability of credit for financing certain essential carrying costs and rehabilitation expenditures. The elimination of fire risks is obviously prerequisite to reasonable credit facilities. Landowners whose principal asset is growing timber may be forced to liqui-

45 For example in the area studied, if the annual tax were reduced from 9 to 2 cents per acre, a 10 per cent tax on the stumpage value $(\$ 8.40$, Table 22$)$ would more than offset the 70 cents per acre loss during the 10-year period, disregarding any interest costs for the state.

16 Matthews, Donald M., Management of American Forests. 1935, pp. 413-18. 
date before maturity or to cut excessively because of financial pressure unless credit can be had with forest resources as security. Credit needs may be particularly great while stands are being restored to a productive state. It is doubtful whether forest credit can be expected from local credit agencies. The period of credit necessarily must be long, and deferred interest loans may be requisite in many instances. Consequently, the risk-bearing base must be broad.

In some respects, these provisions for encouraging private property represent subsidies from public sources. Perhaps such subsidies are appropriate to encourage private initiative. It is not likely, however, that these procedures would be effective in interesting all owners in practicing long-time forest management. ${ }^{7}$ Consequently, to the extent that the obstacles to forest conservation under the present tenure and operational pattern are not removed, and to the extent that forest owners remain uninterested in long-range forest management, it is clear that public control measures are requisite, if continued exploitation of the forest resources of central West Virginia is to be prevented. Moreover, large areas of West Virginia woodland is so thoroughly depleted and otherwise unproductive of merchantable timber for long periods that public ownership and development appears to be the only feasible recourse to future productivity. In this respect, the Public Land Corporation has an important service to perform. Inasmuch as it is authorized to take title to and provide for the development of land reverting to the state through tax delinquency, 48 it is suggested that this corporation, aided by the State Planning Board, formulate a positive policy of retaining lands unsuited for continued enterprise, in the custody of the state for development and protection. In order to block small tracts for administration it probably will be desirable to purchase adjoining lands before they revert through the process of delinquency.

The program being administered by the United States Forest Service on the Monongahela National Forest occupies a central position in the conservation and rehabilitation of forest resources in West Virginia. It undoubtedly will continue to do so. However, the problems are so extensive that it challenges all the resources of both state and federal agencies to cooperate in the solution.

It is entirely possible that a utilization program similar to that discussed previously as forest-farm homesteads might be provided on public lands as the labor requirements of the forest permit. By this method the numerous difficulties and uncertainties that would probably be encountered in an attempt to establish privately-

47 For example, the Agricultural Adjustrrent Administration offered subsidies, during the period $1936-1940$, of $\$ 7.50$ and $\$ 3.00$ per acre for planting trees and stand improvement, respectively. In 1942 the subsidy program was discontinued primarily because of a lack of participation.

48 It is assumed that the corporation will be provided with the essential statutory authority, in lieu of the portion of the present Chapter 11-A which was declared unconstitutional (Sims, et al. $v$. Fischer), to permit it to function according to original intentions. 
owned operating units could be eliminated, and the number of people depending on the land could be adjusted as merchantable resources permit. Furthermore, the administration and supervisory procedure could be greatly simplified by definite contractual and regulatory measures. Inasmuch as the public will probably shoulder the responsibility for both human welfare and land resource rehabilitation in any event, the lower the costs and the greater the simplicity of the administration, the greater the certainty of success.

There are two major disadvantages, however, of depending entirely on tax reversion for the acquisition of land to be rehabilitated and conserved. First, this may be a slow process, and private owners may so completely deplete the growing stock by cutting all potentially good young timber for mine props and charcoal that future production might be permanently jeopardized. Second, the process of tax delinquency usually reduces the people, as well as the land, to exhaustion. It would be in the interests of general welfare to anticipate this eventuality and prevent it where feasible by public purchase.

It has been indicated that at least ten years will be required for producing a merchantable harvest of an economical volume from present stands. Further delay in obtaining protection may extend the period required for rehabilitation to 25,50 , or even 100 years. Every year of continued exploitation further reduces the feasibility of private forestry. As the initial phases of this study were completed (February 1942) war-time demands for lumber and mine timbers were spurring timber operators to expand production. Unrestricted cutting of timber of all sizes for lumber, mine supplies, and charcoal is now proceeding at an unprecedented rate. By the time the war ends, the growing forest inventories will be greatly reduced, and the hurried cutting will have left the land in even worse condition than it has been heretofore. The length of time required for rehabilitation will surely be extended; and the problems of private ownership, taxation, and conservation will be intensified.

War-time demands for labor are encouraging reductions in the underemployed populations of areas of the type studied here. Following the war it will be imperative that such gains in man-land adjustment be maintained in the interests of long-time economic and social welfare. It should be recognized however, that permanent adjustments in land use, population, and institutions may necessitate definite and positive action by the public. The resources of this area are suitable only for forest production, with few exceptions. The joint and related benefits to be derived from this type of land utilization make it imperative that society take steps to insure a minimum of forest conservation. On the other hand, it is obvious that the public should not practice the subsidy of forest development and conservation without some guarantee that society will realize the benefits. 


\section{SUMMARY AND CONCLUSIONS}

In general, the practices of forest operators have been inconsistent with long-time forest production. Large areas have already been sold to the National Forest. Present owners indicate a desire to liquidate the resource, having no long-time interest in forest management. Little or no constructive relationship exists between subsistence farming in Nicholas and Webster Counties and forest operations, inasmuch as the small acreage owned by farmers is in a very poor state of productivity.

The man-land ratio is relatively high, and relief constitutes a large proportion of family income. Young people have had a tendency to "dam up" on low quality land, principally because of a total lack of vocational training and discipline to fit them for productive work in the mining and industry of the surrounding area. Large numbers of family units are located on small, privatelyowned tracts, much of the cleared land of which is reverting to forest cover. A number of families are "squatting" on lands owned in large tracts by lumbering and mining interests.

Approximately half of the land in the two counties is owned in tracts of 500 acres or more. Much of it is being held, not for long-time timber management, but in anticipation of coal development. Although taxes are reasonably low, a number of large tracts are chronically delinquent. Other large tracts have been held by private owners through an extra-legal procedure of revaluation and redemption, whereby the taxes levied have been reduced as much as 80 per cent in numerous cases. The state has followed a policy of maintaining land in private ownership, even though a large proportion of the taxes levied, including delinquent penalties and interest, had to be cancelled. A continuation of present practices will reduce forest land resources to an extremely low state of productivity.

Little progress has been made in the two counties toward adopting programs of forest improvement and development, except on the land owned as a part of the Monongahela National Forest. The West Virginia Agricultural Experiment Station is investigating the cooperative approach to profitable forest management and marketing in central West Virginia, but at present the program is adapted primarily to those lands from which some harvest is possible. The program of subsidy for forest planting and improvement administered by the Agricultural Adjustment Administration was a failure, principally because of a lack of interest in future forest production. There is, however, a fire protective organization sponsored by the State Conservation Commission, in which a number of forest owners participate.

The evaluation of forest resources indicated a growth sufficient to justify a continuation of private property, except for (1) the long-term risks not coverable by interest charges, and (2) the 
pressure to gain some income during a period which should be allowed for rehabilitation of production. An evaluation of the feasibility of a closer relationship between farming and forestry in the form of forest-farm homesteads indicated that a frugal, hard working people who were willing to live at a subsistence level would find 200 -acre forest units practical as family working units, following a ten-year period of growth rehabilitation, based on the stand inventory of 1941. Since this inventory is being further reduced, the length of time required for rehabilitation probably will be much longer. Getting from a current state of almost no productivity to a condition in the future when private property might be feasible is the major obstacle to forest-farm homesteads. A possible further obstacle might be the absence of a hardwood pulpwood market as a basis for short-term rotation cutting.

There are two major factors which must be considered in pointing the way toward forest conservation for this portion of the Appalachians: (1) the people; and (2) the land. It is clear that a large proportion of the people are now underemployed, and that the potential future productivity of forest resources cannot be expected to absorb all those now living at a subsistence level. In Hacker Valley District it was estimated that the potential employment after rehabilitation, could support only 75 per cent of the family units now in the area. In the interests of greater forest resource conservation, and continuous private forest enterprise, there are four measures which may encourage landowners and forest operators to practice long-range forest management. (1) Educational programs designed to acquaint owners and operators of the potential productivity of forest lands under sustained yield management. (2) More adequate fire prevention and control services. (3) Modification of the present forest property tax might reduce the carrying costs on cut-over lands to the extent that potential future production would not be discounted so highly. (4) Establishment of long-term credit facilities for development and rehabilitation of forest lands.

More complete finishing of rough lumber as is now done in many cases, and the development of other industries in the area, may provide employment for some of the excess population. However, the prospects for these developments are not encouraging, at least for some time. Consequently, it is suggested that some employable families might be relocated in areas deficient in manpower. This would be consistent with the desirable use of both human and land resources. In the interest of longer-term adjustment of population to resources it is imperative that vocational education be provided for the large number of young men and women so that they will be fitted to accept employment in other areas.

If private owners do not accept and practice desirable policies of resource development and conservation it will be imperative that public control and regulation of forest land be provided. Other- 
wise, depletion may continue at an accelerated rate. Furthermore, certain forest areas have such low productivity that public ownership is the only recourse. Accordingly it is recommended that the Public Land Corporation of West Virginia accept an exacting policy of retaining for development all lands reverting through the process of tax delinquency which is not immediately suitable for private ownership. Additional public purchase may be necessary in order to combine tracts for economical development, and to forestall the exhaustion of both human and land resources. It should be recognized that continued delay in taking measures for achieving forest land conservation adds greatly to the future cost of rehabilitation. 
- 




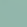


